\title{
A new method for inferring city emissions and lifetimes of nitrogen oxides from high-resolution nitrogen dioxide observations: a model study
}

\author{
Fei Liu ${ }^{1,2, a}$, Zhining Tao ${ }^{1,2, a}$, Steffen Beirle ${ }^{3}$, Joanna Joiner ${ }^{2}$, Yasuko Yoshida ${ }^{2,4}$, Steven J. Smith ${ }^{5}$, \\ K. Emma Knowland ${ }^{1,2, a}$, and Thomas Wagner ${ }^{3}$ \\ ${ }^{1}$ Universities Space Research Association (USRA), \\ Goddard Earth Sciences Technology and Research (GESTAR), Columbia, MD 21046, USA \\ ${ }^{2}$ NASA Goddard Space Flight Center, Greenbelt, MD 20771, USA \\ ${ }^{3}$ Max-Planck-Institut für Chemie, 55128 Mainz, Germany \\ ${ }^{4}$ Science Systems and Applications Inc., Lanham, MD 20706, USA \\ ${ }^{5}$ Joint Global Change Research Institute, Pacific Northwest National Laboratory, \\ College Park, MD 20740, USA \\ ${ }^{a}$ now at: Morgan State University, Goddard Earth Sciences Technology and Research (GESTAR) II, \\ Baltimore, MD 21251, USA \\ Correspondence: Fei Liu (fei.liu@ @asa.gov)
}

Received: 30 July 2021 - Discussion started: 19 August 2021

Revised: 25 November 2021 - Accepted: 7 December 2021 - Published: 26 January 2022

\begin{abstract}
We present a new method to infer emissions and lifetimes of nitrogen oxides $\left(\mathrm{NO}_{x}\right)$ based on tropospheric nitrogen dioxide $\left(\mathrm{NO}_{2}\right)$ observations together with reanalysis wind fields for cities located in polluted backgrounds. Since the accuracy of the method is difficult to assess due to lack of "true values" that can be used as a benchmark, we apply the method to synthetic $\mathrm{NO}_{2}$ observations derived from the NASA-Unified Weather Research and Forecasting (NU-WRF) model at a high horizontal spatial resolution of $4 \mathrm{~km} \times 4 \mathrm{~km}$ for cities over the continental United States. We compare the inferred emissions and lifetimes with the values given by the NU-WRF model to evaluate the method. The method is applicable to 26 US cities. The derived results are generally in good agreement with the values given by the model, with the relative differences of $2 \% \pm 17 \%$ (mean \pm standard deviation) and $15 \% \pm 25 \%$ for lifetimes and emissions, respectively. Our investigation suggests that the use of wind data prior to the satellite overpass time improves the performance of the method. The correlation coefficients between inferred and NU-WRF lifetimes increase from 0.56 to 0.79 and for emissions increase from 0.88 to 0.96 when comparing results based on wind fields sampled simultaneously with satellite observations and averaged over $9 \mathrm{~h}$ data prior to satellite observations, respectively. We estimate that uncertainties in $\mathrm{NO}_{x}$ lifetime and emissions arising from the method are approximately $15 \%$ and $20 \%$, respectively, for typical (US) cities. The total uncertainties reach up to $43 \%$ (lifetimes) and $45 \%$ (emissions) by considering the additional uncertainties associated with satellite $\mathrm{NO}_{2}$ observations and wind data. We expect this new method to be applicable to $\mathrm{NO}_{2}$ observations from the TROPOspheric Monitoring Instrument (TROPOMI) and geostationary satellites, such as Geostationary Environment Monitoring Spectrometer (GEMS) or the Tropospheric Emissions: Monitoring Pollution (TEMPO) instrument, to estimate urban $\mathrm{NO}_{x}$ emissions and lifetimes globally.
\end{abstract}




\section{Introduction}

Nitrogen oxides $\left(\mathrm{NO}_{x}\right)$, consisting of nitrogen dioxide $\left(\mathrm{NO}_{2}\right)$ and nitric oxide (NO), are important atmospheric trace gases that actively participate in the formation of tropospheric ozone and secondary aerosols and accordingly have a significant effect on human health and climate (Seinfeld and Pandis, 2006). $\mathrm{NO}_{x}$ emission sources include anthropogenic activities, biomass burning, soil emissions, and lightning. Fossil-fuel burning from mobile and industrial emitters represents the largest source of anthropogenic $\mathrm{NO}_{x}$ emissions; these sources are usually clustered near densely populated urban areas (Crippa et al., 2018).

We traditionally rely on a bottom-up method to estimate anthropogenic $\mathrm{NO}_{x}$ emissions for a country or a region based on their total fuel use and averaged emission factors, which are subject to uncertainties due to incomplete understanding of real-world operating conditions and spatial distributions (Butler et al., 2008). Some sources may be missing from bottom-up emission inventories (McLinden et al., 2016). Additionally, estimates of $\mathrm{NO}_{x}$ emissions may become outdated when fuel consumption and emission factors change dramatically. For instance, $\mathrm{NO}_{x}$ emissions from China decreased by $21 \%$ from 2011 to 2015 due to wide deployment of denitration devices (Liu et al., 2016a). Inferring emissions for individual cities is even more challenging, due to the difficulties in acquiring a complete and reliable database for fuel consumptions and emission factors at city level. Proxies such as population density, industrial productivity, and road network maps are often used to downscale national/regional emissions to finer scales, which may incorrectly allocate emission sources spatially (Butler et al., 2008).

Satellite observations of tropospheric $\mathrm{NO}_{2}$ have been widely used to infer the strength of $\mathrm{NO}_{x}$ emissions. Satellite instruments, e.g., the Ozone Monitoring Instrument (OMI; Levelt et al., 2006, 2018) and TROPOspheric Monitoring Instrument (TROPOMI; Veefkind et al., 2012), are used to retrieve the column density of $\mathrm{NO}_{2}$ in a vertical column of air. These data can then be related to $\mathrm{NO}_{x}$ emissions by considering chemical conversion and transport. Chemical transport models (CTMs) were initially employed to use $\mathrm{NO}_{2}$ measured from space as a constraint to improve $\mathrm{NO}_{x}$ emission inventories based on mass balance (e.g., Martin et al., 2003; Kim et al., 2009; Lamsal et al., 2011). Techniques such as the four-dimensional variational (4D-Var) method (e.g., Henze et al., 2007, 2009), extended Kalman filter (e.g., Ding et al., 2017), ensemble Kalman filter (e.g., Miyazaki et al., 2017), and hybrid mass balance/4D-Var (e.g., Qu et al., 2019) have also been used to improve emissions estimates within CTMs.

Several studies have inferred emissions independent of CTMs (e.g., Beirle et al., 2011; Liu et al., 2017; Laughner and Cohen, 2019). Such investigations were inspired by a pioneering study that used the downwind decay of $\mathrm{NO}_{2}$ in continental outflow regions to estimate the global $\mathrm{NO}_{x}$ lifetime and total emissions (Leue et al., 2001). Beirle et al.
(2011) first proposed an empirical function to describe the plume distribution around an isolated city without inputs from CTMs. Follow-up studies have adopted this function to provide estimates of $\mathrm{NO}_{x}$ emissions from power plants and cities based on OMI (e.g., de Foy et al., 2015 and Lu et al., 2015) and TROPOMI (e.g., Goldberg et al., 2019) observations. Additional methods, such as the plume rotation technique (Pommier et al., 2013; Valin et al., 2013) and the divergence approach (Beirle et al., 2019), were developed to refine the approach of Beirle et al. (2011). More recent studies explored additional constraints for the empirical function using simulated atmospheric composition from models (e.g., Lorente et al., 2019; Lange et al., 2021). For sources with a polluted background, Liu et al. (2016b) proposed a different fitting function to consider the interferences from surrounding sources; this approach has been used to estimate $\mathrm{NO}_{x}$ emissions for European cities (Verstraeten et al., 2018).

The uncertainties in satellite-derived emissions inferred from CTM-independent approaches have rarely been investigated. Field campaigns, e.g., Deriving Information on Surface Conditions from Column and Vertically Resolved Observations Relevant to Air Quality (DISCOVER-AQ), Korea-United States Air Quality Study (KORUS-AQ), and Cabauw Intercomparison of Nitrogen Dioxide Measuring Instruments 2 (CINDI-2), have been performed to better quantify errors in the $\mathrm{NO}_{2}$ observations (e.g., Choi et al., 2020) and therefore improve knowledge about uncertainties in satellite-derived emissions. Existing studies usually quantify the uncertainties based on results from sensitivity analyses (e.g., Beirle et al., 2011), since we usually lack "true values" that can be used as a benchmark for validation. De Foy et al. (2014) tested CTM-independent approaches using simulated $\mathrm{NO}_{2}$ column densities from a single-point source with a specified emission and chemical lifetime. The good consistency between the derived values and the specified values given to drive the simulation suggests that the uncertainty of the Beirle et al. (2011) approach is small for an ideal, isolated source. However, the performance of the approach in the real world with complex source distributions has not yet been evaluated.

Here, on the basis of previous approaches (Beirle et al., 2011; Liu et al., 2016b), we develop a new CTM-independent approach for inferring $\mathrm{NO}_{x}$ lifetimes and emissions for cities with polluted backgrounds and complex spatial distribution of interfering emissions. We use synthetic $\mathrm{NO}_{2}$ observations derived from a model simulation to evaluate the performance of the new approach and to estimate its uncertainties. An overview of the synthetic observations, the methodology and features of the new CTM-independent approach is provided in Sect. 2. We evaluate results by comparing the inferred emissions and lifetimes with values from the model simulation in Sect. 3.1. Section 3.2 compares the performance of the method developed in this work with previous approaches (Beirle et al., 2011; Liu et al., 2016b). Section 3.3 discusses the uncertainties of $\mathrm{NO}_{x}$ lifetimes and emissions derived 


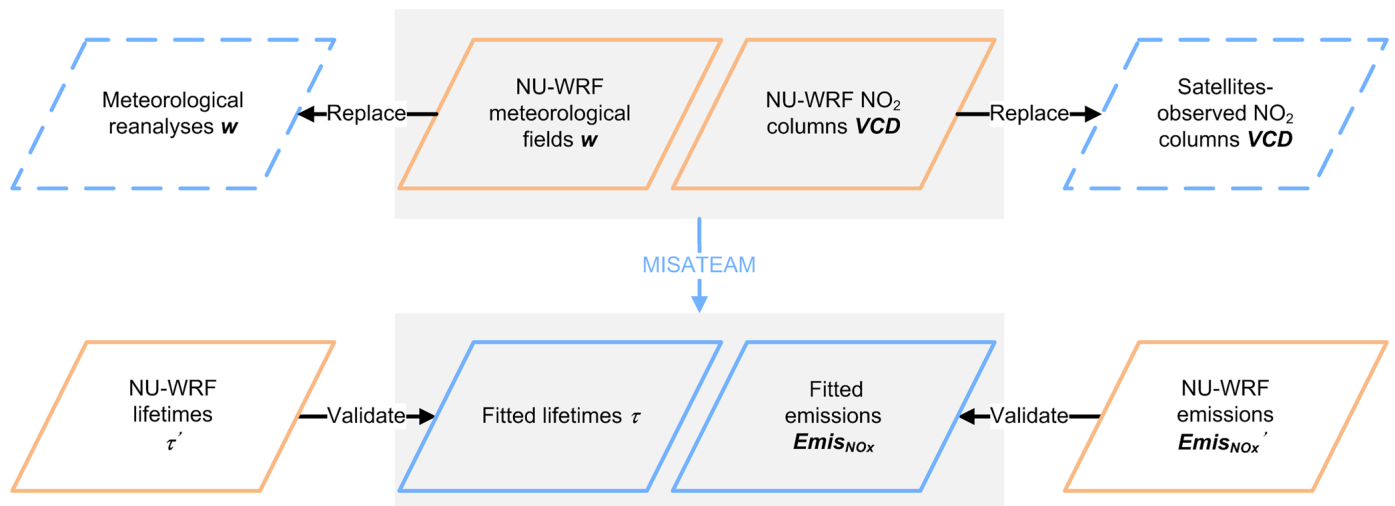

Figure 1. Schematic of our evaluation system to assess the accuracy of the inferring $\mathrm{NO}_{x}$ lifetimes and emissions derived from MISATEAM. The blue symbols represent the inputs (dashed line) and outputs (solid line) of MISATEAM. The orange symbols represent the information derived from NU-WRF.

from the new approach. Section 4 presents a summary of the performance of the new method and future work plans for applying the method to satellite observations.

\section{Data and method}

In this section, we develop an evaluation system to assess the performance of our newly developed CTM-Independent SATellite-derived Emission estimation Algorithm for Mixedsources (MISATEAM). Figure 1 displays the schematic of the evaluation system. MISATEAM uses satellite retrievals of tropospheric $\mathrm{NO}_{2}$ vertical column densities (VCDs), together with wind information from a meteorological reanalysis, to infer $\mathrm{NO}_{x}$ lifetimes and emissions for cities. Cities are usually non-isolated sources with polluted backgrounds (Fig. S1 in the Supplement). Additionally, emissions from cities may spread out and make cities not (quasi) point sources, even at the footprint of satellite observations (a few kilometers; Fig. 3). We refer to these cities as mixed sources.

To evaluate MISATEAM, we replace satellite observations with synthetic $\mathrm{NO}_{2}$ VCDs derived from the NASA-Unified Weather Research and Forecasting (NU-WRF) model (Tao et al., 2013; Peters-Lidard et al., 2015) (Sect. 2.1). We then apply MISATEAM to the synthetic $\mathrm{NO}_{2}$ VCDs and NUWRF meteorological fields to infer urban $\mathrm{NO}_{x}$ lifetimes and emissions (Sect. 2.2). We investigate the impact of temporal variations in wind fields on derived $\mathrm{NO}_{x}$ lifetimes and emissions (Sect. 2.3). In Sect. 2.4, we describe the benchmark $\mathrm{NO}_{x}$ emissions directly given by NU-WRF and $\mathrm{NO}_{x}$ lifetimes deduced from known $\mathrm{NO}_{x}$ emissions and concentrations (hereafter referred to as "given emissions and NUWRF lifetimes") that we will compare with the MISATEAMderived lifetimes and emissions. Analysis of the uncertainties in these datasets, including satellite observations and wind fields, is outside the scope of the study. We briefly discuss the potential impact of ignoring systematic errors in Sect. 3.3.2.

\subsection{Synthetic $\mathrm{NO}_{2}$ VCDs: NU-WRF simulations}

We use a regional modeling system, NU-WRF (Tao et al., 2013; Peters-Lidard et al., 2015), to simulate tropospheric $\mathrm{NO}_{2}$ VCDs over the continental United States. NU-WRF was developed from the advanced research versions of WRF (Michalakes et al., 2001) and WRF-Chem (Grell et al., 2005) with the addition of several NASA-developed components (e.g., Chou and Suarez, 1999; Chin et al., 2002, 2007; Kumar et al., 2006; Peters-Lidard et al., 2007; Shi et al., 2010). The gas-phase chemical mechanism in NU-WRF is the second-generation regional acid deposition model (RADM2; Gross and Stockwell, 2003). The aerosol module is the Goddard Chemistry Aerosol Radiation and Transport (GOCART) model (Chin et al., 2002). We use the anthropogenic emissions based on the 2011 National Emissions Inventory (NEI) compiled by the US Environmental Protection Agency (US EPA, NEI 2011) but with a few modifications, in which the measurements from OMI, the ground-based Air Quality System (AQS), the in situ continuous emissions monitoring in power plants, and the Air Pollutant Emissions Trends Data compiled by the US EPA (https://www.epa.gov/air-emissionsinventories/air-pollutant-emissions-trends-data, last access: 1 December 2021) have been employed to adjust the baseline emissions to the simulation year of 2016 (Tong et al., 2015; Tao et al., 2020). As such, the total anthropogenic $\mathrm{NO}_{x}$ emissions in 2016 were approximately $72 \%$ of those in 2011 , the baseline NEI year. The simulation also includes the fire emissions from the Global Fire Data version 4 with small fires (GFED v4s; van der Werf et al., 2017; Randerson et al., 2015); biogenic emissions from the online calculation using the Model of Emissions of Gases and Aerosols from Nature version 2 (MEGAN2; Guenther et al., 2006); dust emissions from the online estimation based on the surface wind speed, soil moisture, and soil erodibility (Ginoux et al., 2001; Kim 
(a)

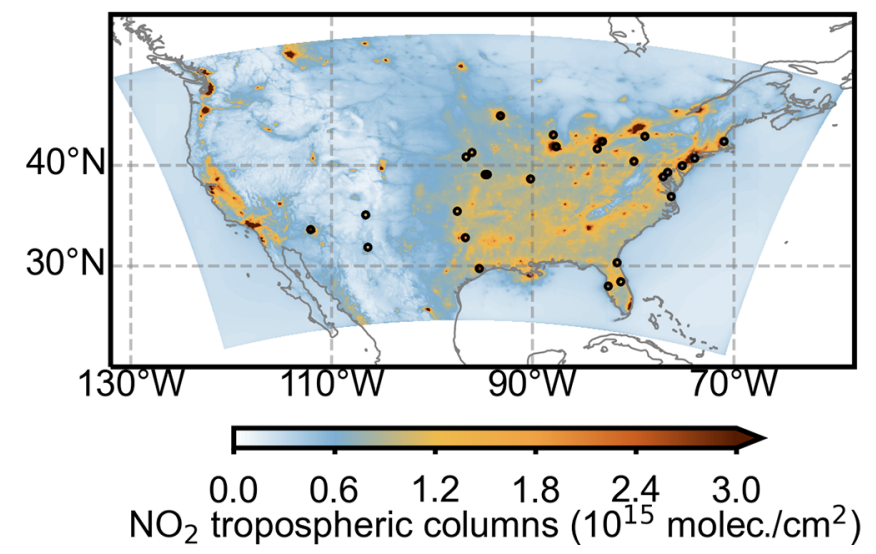

(b)

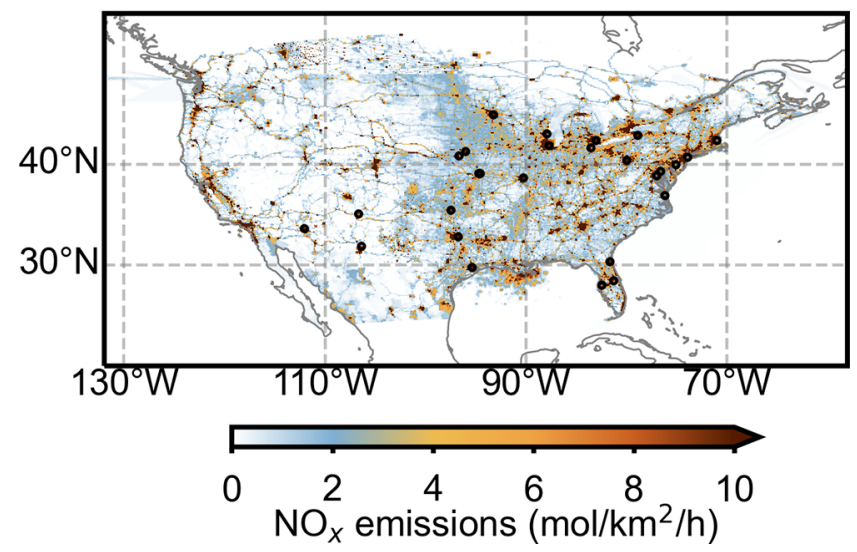

Figure 2. Domain used for simulation. (a) Mean NU-WRF tropospheric $\mathrm{NO}_{2}$ vertical column densities. (b) Mean NEI NO$x$ emissions fluxes used to drive the NU-WRF simulation. Hourly mean data at 14:00 LT are averaged from April through September 2016. Locations of the 26 cities investigated in this study are shown by circles (see Sect. 3).

et al., 2017); and sea salt emissions from the online computation based on the method by Gong (2003).

We run NU-WRF for 2016 at a high horizontal spatial resolution of $4 \mathrm{~km} \times 4 \mathrm{~km}$ and 40 vertical layers extending from the surface to $50 \mathrm{hPa}$ in this study. Figure 2 illustrates the domain of the simulation, which covers the continental United States. We integrate $\mathrm{NO}_{2}$ concentrations from the surface to the tropopause to calculate tropospheric $\mathrm{NO}_{2}$ VCDs. We assume a consistent tropopause height of $10 \mathrm{~km}$ over the model domain to accelerate the data process because NUWRF outputs do not include tropopause height, and $\mathrm{NO}_{2}$ VCDs integrated above $10 \mathrm{~km}$ increase slightly. We have performed a sensitivity analysis by integrating $\mathrm{NO}_{2}$ concentrations from the surface to altitudes ranging from 8 to $16 \mathrm{~km}$, where the seasonal mean tropopause heights may occur over the United States (Pan et al., 2011; Rieckh et al., 2014). The derived $\mathrm{NO}_{2}$ VCDs over the fit domain of individual cities vary slightly above $10 \mathrm{~km}$, with the relative difference of $3 \% \pm 2 \%$ when increasing the integration altitude from 10 to $12 \mathrm{~km}$, since most $\mathrm{NO}_{2}$ stays near the surface over the polluted urban areas. The meteorological initial and lateral boundary conditions are derived from the Modern Era Retrospective-Analysis for Research and Applications version 2 (MERRA-2; Rienecker et al., 2011; Gelaro et al., 2017). The chemical initial and lateral boundary conditions are derived from the results of the Community Atmosphere Model with chemistry (CAM-chem; Lamarque et al., 2012). A $7 \mathrm{~d}$ model spin-up following the recommendation by Berge et al. (2001) is used.

Figure 2a illustrates the 6-month average of the simulated hourly mean tropospheric $\mathrm{NO}_{2}$ VCDs sampled at 14:00 LT, which approximately corresponds to the early afternoon overpass time of OMI and TROPOMI. The $\mathrm{NO}_{x}$ emissions used to drive NU-WRF over the model domain for the same time period are presented in Fig. 2b. We focus on cities with populations $>200000$, which have been defined as mediumsize urban areas in Organisation for Economic Co-operation and Development (OECD) countries. Nearby cities (located within $50 \mathrm{~km}$ of the largest city in a given urban area) are considered as one city cluster when applying MISATEAM to infer lifetimes and emissions. Cities on the boundary of the model domain, e.g., Seattle and San Francisco, are excluded from the following analysis because the data for their inflow/outflow plumes are partially missing from the model output and thus do not meet the requirements of MISATEAM (see details of the fit interval in Sect. 2.2). This filtering results in a total of 60 cities and urban conglomerations (see Table S1 in the Supplement) as the candidates for applying MISATEAM, of which 26 have valid results. The locations of the 26 cities are shown in Fig. 2. Cities without valid results either lack observations under calm wind conditions or are associated with large fitting errors (see details in Sect. 3.1).

\subsection{Emission estimation algorithm}

We develop MISATEAM based on the methods of Beirle et al. (2011) and Liu et al. (2016b). We develop a new model function aiming for determining emissions for mixed sources, instead of isolated sources, within a clean background considered by Beirle et al. (2011). It is also different from that of Liu et al. (2016b), which was developed for complex sources but adapted an additional model function to fit emissions in a separate step. More comparisons with those two previous methods will be discussed in Sect. 3.2.

We adapt the basic approach of Liu et al. (2016b) that estimates $\mathrm{NO}_{2}$ emission rates, $E(x)$, using $\mathrm{NO}_{2}$ observations, $\operatorname{LD}_{\text {calm }}(x)$, following

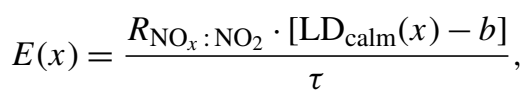


where $E(x)$ is a function of distance from the city center (denoted by $x$ ) in a particular direction and integrated over a given distance in a direction $y$ (perpendicular to that of $x$ ). The mean emission maps (two-dimensional, 2D) are reduced to $1 \mathrm{D}$ along the respective direction $x$ by integration across the direction $y$. $\operatorname{LD}_{\text {calm }}(x)$ is the so-called $\mathrm{NO}_{2}$ line densities, defined as the observed $\mathrm{NO}_{2}$ VCDs (units molec. $\mathrm{cm}^{-2}$ ) under calm wind conditions (wind speed $<2 \mathrm{~m} \mathrm{~s}^{-1}$ ), integrated in the same way as $E(x)$ to give units of molecules per centimeter (molec. $\mathrm{cm}^{-1}$ ) as in Beirle et al. (2011).

$R_{\mathrm{NO}_{x}}: \mathrm{NO}_{2}$ is the ratio of $\mathrm{NO}_{x}$ to $\mathrm{NO}_{2}$. We use $R_{\mathrm{NO}_{x}}: \mathrm{NO}_{2}$ of 1.32 to represent "typical urban conditions and noontime sun" (Seinfeld and Pandis, 2006). We investigate the effect of using a constant value of $R_{\mathrm{NO}_{x}}: \mathrm{NO}_{2}$ on derived emissions in Sect. 3.1; it is found to be insignificant.

$b$ represents the $\mathrm{NO}_{2}$ background for each city, which is derived by analyzing the distribution of $\mathrm{NO}_{2} \mathrm{VCDs}$. We first calculate the mean $\mathrm{NO}_{2} \mathrm{VCD}$ under calm wind conditions for grid cells within the lowest 5th percentile of $\mathrm{NO}_{2} \mathrm{VCDs}$ for each city. This produces a good approximation of the mean $\mathrm{NO}_{2} \mathrm{VCD}$ for grid cells with low $\mathrm{NO}_{x}$ emissions (i.e., the lowest 5 th percentile of $\mathrm{NO}_{x}$ emissions). We then multiply this mean VCD value by the spatial width of the acrosswind integration interval to derive $b$.

$\tau$ is the $\mathrm{NO}_{x}$ lifetime. Note that $\tau$ is assumed to be an effective mean dispersion lifetime (i.e., the result of the effect of deposition, chemical conversion, and wind advection) because we do not consider downwind changes in the fitting functions, such as due to variations in wind speeds or



We then use the following model function, $f(x)$, to describe $\mathrm{NO}_{2}$ line densities under windy conditions (wind speed $>2 \mathrm{~m} \mathrm{~s}^{-1}$ ) $\operatorname{LD}_{\text {windy }}(x)$ :

$$
\begin{aligned}
f(x) & =\frac{E(x)}{R_{\mathrm{NO}_{x}: \mathrm{NO}_{2} \cdot w} * e^{-\frac{x}{w \cdot \tau}}+b} \\
& =\frac{\left[\mathrm{LD}_{\mathrm{calm}}(x)-b\right]}{\tau \cdot w} * e^{-\frac{x}{w \cdot \tau}}+b,
\end{aligned}
$$

where $w$ is the mean wind speed at the emission level in a given direction $x$, and $*$ denotes convolution. Figure 3 illustrates the calculation of $\mathrm{LD}_{\text {windy }}(x)$. Additional technical details of the model function $f(x)$ and its differences compared to those proposed by Liu et al. (2016b) are given in Appendix A.

Finally, we use estimates of $b$ and $R_{\mathrm{NO}_{x}}: \mathrm{NO}_{2}$ in Eq. (2), along with values of $w, \operatorname{LD}_{\text {calm }}(x)$, and $\operatorname{LD}_{\text {windy }}(x)$ from the model simulation to infer $\tau$ and $E(x)$. As displayed in Fig. 1, we use the NU-WRF high-resolution tropospheric $\mathrm{NO}_{2}$ VCDs sampled at 14:00 LT as the synthetic $\mathrm{NO}_{2} \mathrm{VCD}$ observations, together with the NU-WRF meteorological wind information, to estimate urban $\mathrm{NO}_{x}$ emissions. In other words, here we assume perfect knowledge of the winds and do not further consider the impact of errors in $w$. As in previous studies, we only analyze data from April to September,

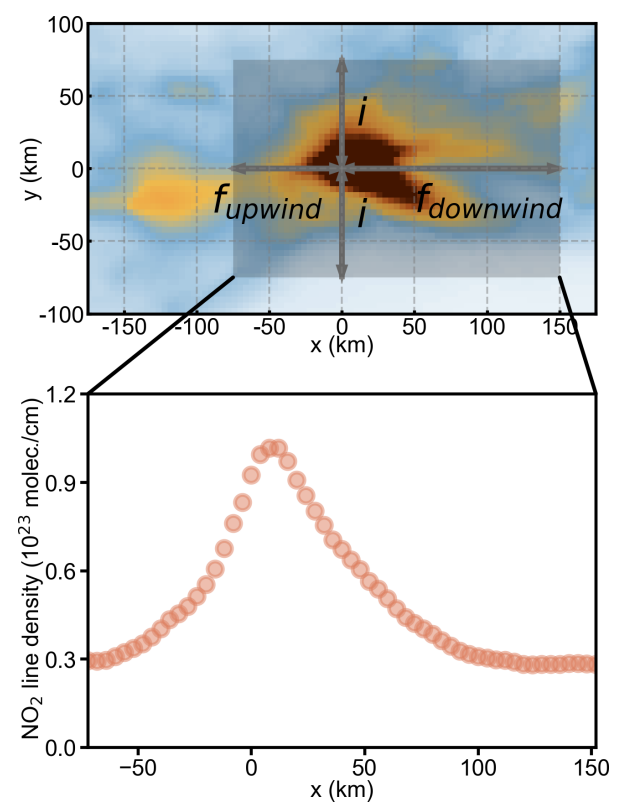

Figure 3. Sketch of the definition of line densities. For each wind direction, mean $\mathrm{NO}_{2}$ VCDs are integrated in across-wind direction $y$ over the interval $i$, resulting in line densities $\operatorname{LD}(x)$. The fit is performed over the entire upwind interval ( $\left.f_{\text {upwind }}\right)$ and downwind interval $\left(f_{\text {downwind }}\right)$. The city center is the coordinate origin. The top panel shows the NU-WRF tropospheric $\mathrm{NO}_{2}$ VCDs around New York City under southwesterly wind; however the image is rotated by $45^{\circ}$ in the clockwise direction to present $\mathrm{NO}_{2}$ VCDs in an upwind-downwind direction. The city of Philadelphia and Long Island are located in the upwind and downwind direction, respectively.

in order to exclude winter data that have larger uncertainties and longer $\mathrm{NO}_{x}$ lifetimes. We also investigate the impact of the inclusion of winter data in Sect. 3.3.1; it is found to be associated with a larger uncertainty. We further compute total emissions for each city, Emis $_{\mathrm{NO}_{x}}$, by summing $E(x)$.

We perform a nonlinear least-squares fit of $f(x)$ to the observed line densities under windy conditions, $\operatorname{LD}_{\text {windy }}(x)$, with $\tau$ as the single fitting parameter. We use the package of scipy.optimize.curve_fit from the Python software library to perform the fitting. We set the fit interval to $150 \mathrm{~km}$ in the downwind direction, which corresponds to the e-folding distance for $\tau=6 \mathrm{~h}$ and $w=7 \mathrm{~m} \mathrm{~s}^{-1}$. The fit intervals in the upwind direction and the $y$ direction are set to half the efolding distance $(75 \mathrm{~km})$; the resulting area is large enough to cover a highly populated and spread-out metropolitan region such as New York City. The definitions of the fit interval in the upwind and downwind direction and the acrosswind integration interval are illustrated in Fig. 3. Note that we use $\operatorname{LD}_{\text {calm }}(x)$ over a larger horizontal interval of $450 \mathrm{~km}$ to calculate the convolution in Eq. (2), in order to eliminate the edge effect of convolution. Fitting results of insufficient quality (i.e., the correlation coefficient $R$ between the fitted and observed $\mathrm{NO}_{2} \mathrm{LD}<0.9$ and 1 standard deviation error 

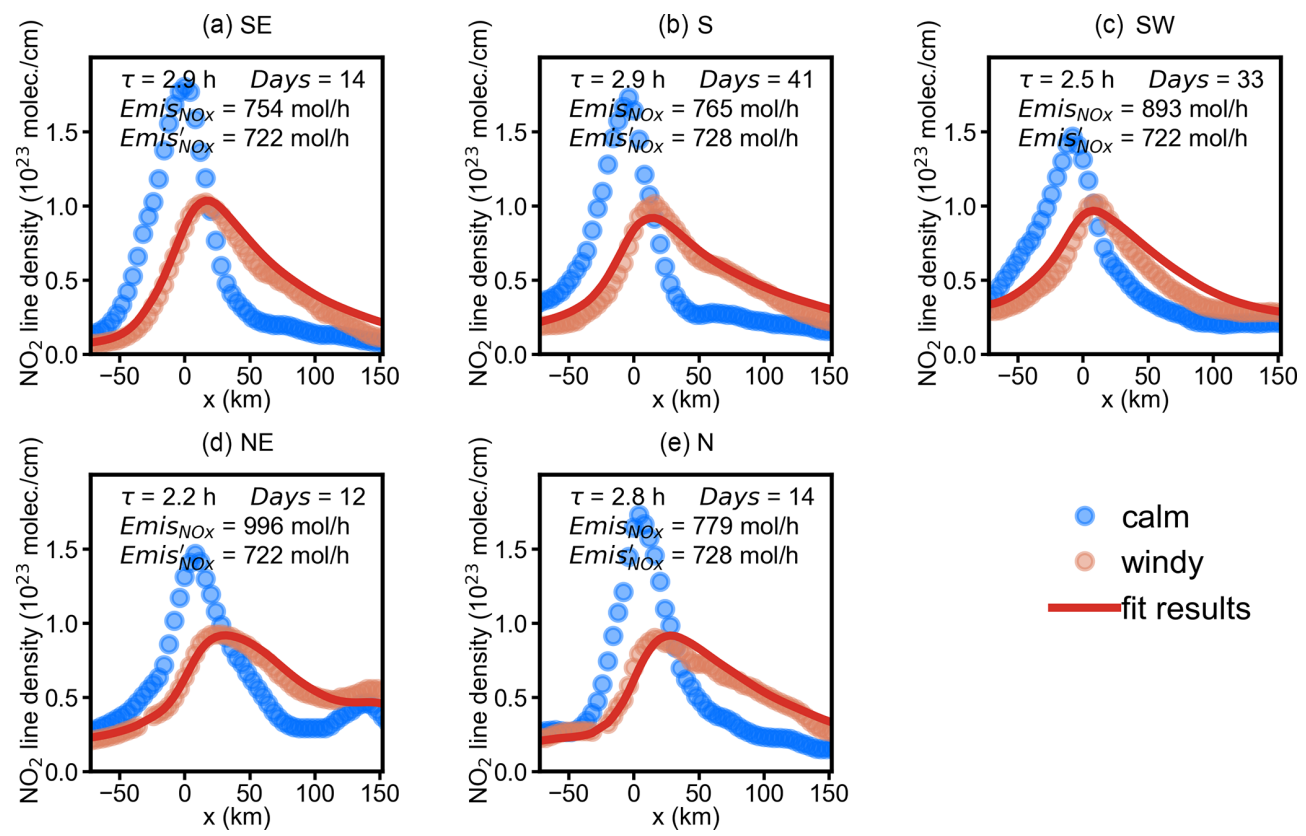

Figure 4. $\mathrm{NO}_{2}$ line densities around New York for different wind direction sectors. Circles: $\mathrm{NO}_{2}$ line densities for calm (blue circles) and (a) southeasterly, (b) southerly, (c) southwesterly, (d) northeasterly, and (e) northerly winds (red circles) as a function of the distance $x$ to the center of New York. Red line: the fit result $f(x)$. The numbers indicate the fitted $\mathrm{NO}_{x}$ lifetime $(\tau)$, average days of data used for calculating $\mathrm{NO}_{2}$ line densities (days), derived emissions (Emis $\mathrm{NO}_{x}$ ), and given emissions $\left(\right.$ Emis $\left._{\mathrm{NO}_{x}}^{\prime}\right) . \mathrm{NO}_{2}$ line densities are derived from $\mathrm{NO}_{2} \mathrm{VCDs}$ averaged from April through September 2016. $\mathrm{NO}_{2}$ line densities for the remaining wind direction sectors are discarded due to the fitting results having insufficient quality.

of $\tau>10 \%)$ are discarded. We infer emissions simultaneously by summing $E(x)$ in Eq. (1). We perform the fit for all wind direction sectors and then average the fitted $\tau$ and corresponding total emission Emis $_{\mathrm{NO}_{x}}$ with good quality, using the fit residuals as inverse weights, to yield a best estimate of $\langle\tau\rangle$ and $\left\langle\right.$ Emis $\left._{\mathrm{NO}_{x}}\right\rangle$ for a given city. The standard deviation of the fit results for different wind directions has been used to quantify uncertainties in Sect. 3.3.2.

We use the city of New York as a case study to demonstrate our approach. This city is well suited for illustrating the strength of MISATEAM to estimate emissions for mixed sources because it is a large city with multiple point and areal sources and is surrounded by many other large sources. Figure 3 displays the complex spatial distribution of sources around New York. Under southwesterly wind, the city of Philadelphia is located in the upwind direction, and Long Island is located in the downwind direction, both of which are significant $\mathrm{NO}_{x}$ sources. Note that we do not exclude cloudy days from our analysis to make the most of the NU-WRF $\mathrm{NO}_{2}$ simulations and to avoid additional uncertainties arising from the inconsistent definitions of cloud fractions in the NU-WRF and satellite $\mathrm{NO}_{2}$ products. The uncertainty of the presence of clouds is discussed in Sect. 3.3.2.

We use wind fields averaged from the surface to $1000 \mathrm{~m}$ altitude for $w$ in this study. The synthetic $\mathrm{NO}_{2} \mathrm{VCDs}$ around New York are sorted by wind direction (Fig. S1). Figure 4a displays the observed line densities for calm (blue circles) and southeasterly winds (red circles) around New York and the fitted model function $f(x)$ (red lines). Generally, $f(x)$ describes the observed downwind patterns very well; the coefficients of determination $\left(R^{2}\right)$ between observation and fit are $0.90-0.98$ for different wind directions. The resulting lifetimes show a range of 2.2-2.9h, which result in emissions of 754-996 $\mathrm{molh}^{-1}$ for different wind directions, as shown in Fig. 4a-e. Results for other wind direction sectors are discarded due to the fitting results being of insufficient quality (westerly and northwesterly winds; Fig. S2 in the Supplement) or a lack of observations (easterly wind).

\subsection{Impact of temporal variations in wind fields}

CTM-independent emission estimation algorithms usually assume a steady wind field over the duration of $\mathrm{NO}_{x}$ lifetime. In the demonstration in Sect. 2.2, we use the wind fields sampled at the satellite overpass time to drive MISATEAM, consistent with previous studies (e.g., Beirle et al., 2011; Valin et al., 2013; Lu et al., 2015; Liu et al., 2017, 2020; Goldberg et al., 2019). This is expected to be reasonable for species with a short lifetime of a few hours such as $\mathrm{NO}_{x}$ near noon of non-winter seasons. In reality, wind fields are variable over the $\mathrm{NO}_{x}$ lifetime. Consequently, $\mathrm{NO}_{x}$ emitted at a time prior to the satellite overpass may be transported under different wind conditions than those at the overpass time. 
(a) $-8 \mathrm{~h}$

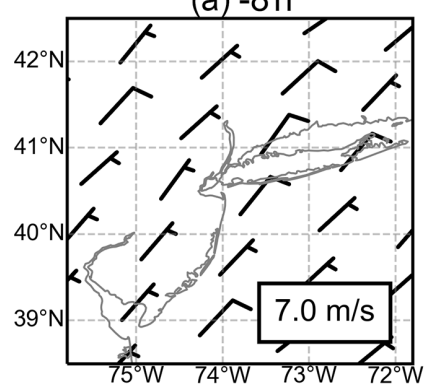

(d) $-5 \mathrm{~h}$

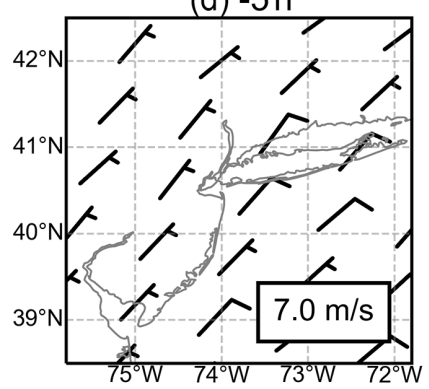

(g) $-2 \mathrm{~h}$

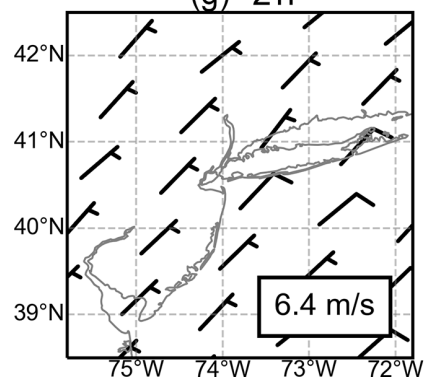

(b) $-7 \mathrm{~h}$

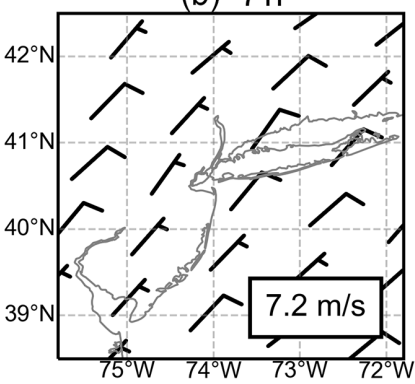

(e) $-4 \mathrm{~h}$

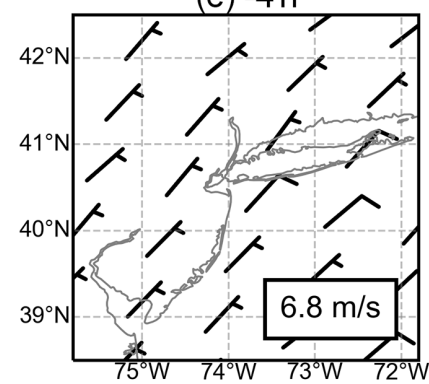

(h) $-1 \mathrm{~h}$



(c) $-6 \mathrm{~h}$

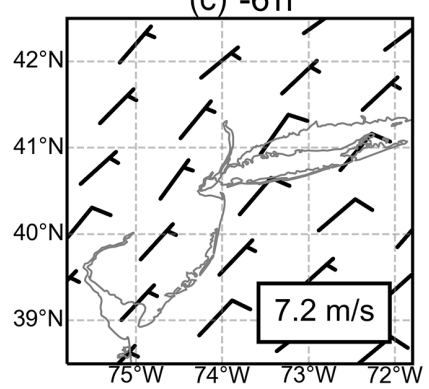

(f) $-3 \mathrm{~h}$

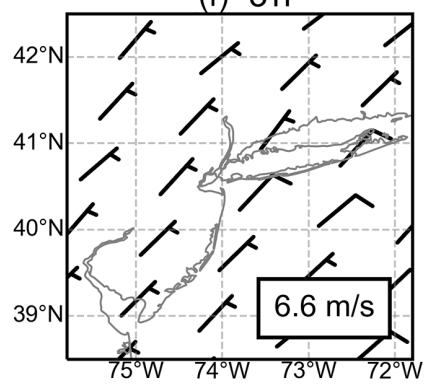

(i) $0 \mathrm{~h}$

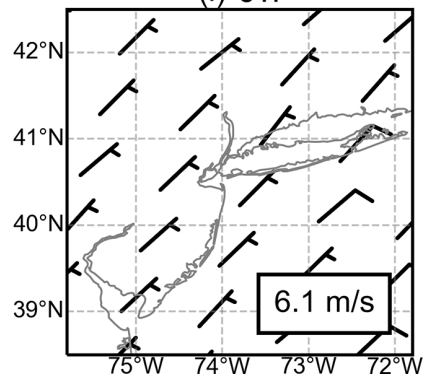

Figure 5. Wind barbs around New York City for different times of the day. All northeasterly winds at 14:00 LT from April to September of 2016 are averaged and shown in (i). Wind barbs for the northeasterly winds backward trajectories from 8 to $1 \mathrm{~h}$ prior to 14:00 LT are displayed in $(\mathbf{a}-\mathbf{h})$. Wind speed is given in units of knots, which is equivalent to nautical miles per hour $\left(1.9 \mathrm{~km} \mathrm{~h}^{-1}\right)$. Each short and long barb represents 5 knots $\left(9.3 \mathrm{~km} \mathrm{~h}^{-1}\right)$ and 10 knots $\left(18.5 \mathrm{kmh}^{-1}\right)$, respectively. The average wind speed is displayed in the grey box.

Figure 5 illustrates the temporal variations in wind fields around New York. We use the northeasterly wind direction (with a good fitting result) for demonstration. We select northeasterly winds observed at 14:00 LT as the baseline and find their backward trajectories for up to $8 \mathrm{~h}$. The backward trajectories are given at a time step of $1 \mathrm{~h}$. Not surprisingly, winds are not constant during the $9 \mathrm{~h}$ from $8 \mathrm{~h}$ before the baseline to the exact hour of the baseline. However, the temporal variations in wind directions are rather small for the northeasterly wind; wind directions are almost constant over time. For wind directions without good fit results, we observe larger variations. For instance, for the westerly wind with a poor correlation coefficient $R$ of 0.76 , the wind directions deviate from the west direction gradually for the time prior to the baseline (Fig. S3 in the Supplement). These results shed light on the robustness of MISATEAM's steadywind assumption. It is most likely that the fit fails when the assumption of steady wind is not satisfied. In other words, the inherent fitting assumption is robust when the fit results have sufficient quality as defined in Sect. 2.2.

We perform sensitivity analyses to investigate the potential impact of temporal variations in winds on the fit results. We extend the time windows used for calculating averaged wind fields from $1 \mathrm{~h}$ (i.e., at the overpass time of 14:00 LT) to $3 \mathrm{~h}$ (i.e., starting from the overpass time and extending into the past $2 \mathrm{~h}$ ), 6, 9, and $12 \mathrm{~h}$. We weight the winds based on their temporal proximity; i.e., the wind closer to the overpass time is given larger weight, following Eq. (3).

$\overline{w_{i, d}}=\frac{\sum_{h=0}^{N} w_{h, i, d} \cdot e^{-h / t 0}}{\sum_{h=0}^{N} e^{-h / t 0}}$,

where $h$ represents the number of hours prior to the overpass time. $i$ and $d$ denote an individual grid cell and day, respectively. $w_{h, i, d}$ is the wind for a specific grid cell $i$ on day $d$ at the time of $h$ hours prior to the overpass time. $N$ is the length of the time window used (units of hour). The weighted 
average winds $\overline{w_{i, d}}$ are further applied with MISATEAM to infer $\mathrm{NO}_{x}$ lifetimes and emissions for investigated cities. We set $t_{0}$ to a constant value of 3 derived from rounding the average NU-WRF lifetimes for all investigated cities (see details in Sect. 2.4). The fitting results are found to be relatively insensitive to the choice of $t_{0}$. The differences of the fitted lifetimes and emissions are $-2 \pm 15 \%$ and $3 \pm 16 \%$, respectively, when we increase $t_{0}$ by a factor of 2 . This is significantly smaller than the difference between the fit results based on weighted average winds and the winds at the overpass time (shown in Sect. 3.1).

\subsection{Performance evaluation}

In order to evaluate the fitting results, we infer given emissions and NU-WRF lifetimes from the NU-WRF inputs/outputs. The given emission Emis $_{\mathrm{NO}_{x}}^{\prime}$ is derived by summing NU-WRF $\mathrm{NO}_{x}$ emissions from all grid cells within the fit interval. The NU-WRF lifetime $\tau^{\prime}$ can be computed by solving Eq. (1); i.e.,

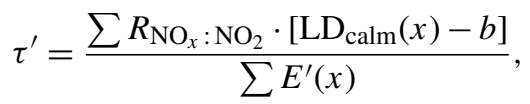

where $E^{\prime}(x)$ is the given $\mathrm{NO}_{x}$ emission line densities under calm wind conditions, as a function of distance $x$ from the city center. For evaluation, we compute the correlation coefficient $(R)$, the normalized mean bias (NMB), and the root mean squared error (RMSE) of the fitted emissions and the given emissions for all investigated cities. The model performance metrics of NMB and RMSE for the emission $\left(\right.$ Emis $_{\mathrm{NO}_{x}}$ ) evaluation are defined as

$\mathrm{NMB}=\frac{\sum_{i=1}^{n}\left(\mathrm{Emis}_{\mathrm{NO}_{x}, i}-\mathrm{Emis}_{\mathrm{NO}_{x}, i}^{\prime}\right)}{\sum_{i=1}^{n} \mathrm{Emis}_{\mathrm{NO}_{x}, i}^{\prime}}$

and

$\operatorname{RMSE}=\sqrt{\frac{\sum_{i=1}^{n}\left(\mathrm{Emis}_{\mathrm{NO}_{x}, i}-\mathrm{Emis}_{\mathrm{NO}, i}^{\prime}\right)^{2}}{n}}$

respectively, where $i$ represents the individual city, and $n$ is the total number of cities used for evaluation. The metrics for lifetime evaluation are consistent with Eqs. (5) and (6) when replacing Emis $_{\mathrm{NO}_{x}}$ with $\tau$ and Emis $_{\mathrm{NO}_{x}}^{\prime}$ with $\tau^{\prime}$. A good method should have a large $R$, a near-zero NMB, and a small RMSE.

\section{Results and discussion}

\subsection{Evaluation}

We apply MISATEAM to 60 large cities over the United States (see the selection criteria of cities in Sect. 2.1). For five cities, we are not able to initiate the fitting procedure, due to a lack of observations under calm wind conditions to calculate $\operatorname{LD}_{\text {calm }}(x)$. We derive valid fitting results for 26 cities.
The locations of the 26 cities are shown in Fig. 2. The other 29 cities without valid results either had small correlation coefficients $(<0.9)$ or large fitting errors (standard deviation error of $\tau>10 \%$ ); those cities tend to have larger temporal variations in winds (similar to Fig. S3), which do not satisfy MISATEAM's requirement for steady winds prior to the satellite overpass.

Figure 6 compares MISATEAM estimated lifetimes and emissions with the NU-WRF lifetimes and given emissions for the 26 cities. The comparison shows good consistency in general. For results derived from the wind data sampled at the overpass time (hereafter referred to as " $1 \mathrm{~h}$ wind"; red dots), values of $R$ are 0.56 and 0.88 for lifetimes and emissions, respectively. The bias is rather small for the lifetime comparison with NMB of -0.04 and RMSE of 0.54 . The bias is larger for emissions, primarily caused by the assumption of

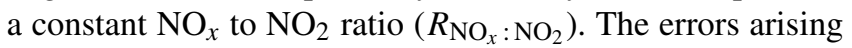
from the differences between $R_{\mathrm{NO}_{x}}: \mathrm{NO}_{2}$ for individual cities and a constant value of 1.32 will be propagated into the resulting emissions. The impact of the prescribed $R_{\mathrm{NO}_{x}}: \mathrm{NO}_{2}$ on inferring emissions will be discussed in more detail in this section (Fig. 7).

The use of wind data over $9 \mathrm{~h}$ prior to the overpass time improves the performance of MISATEAM. Figure $6 \mathrm{com}-$ pares the inferred lifetimes and emissions based on the $9 \mathrm{~h}$ weighted average of wind data (hereafter referred to as " $9 \mathrm{~h}$ wind"; blue dots). The results derived from the weighted average wind data show larger correlations with $R$ increasing from 0.56 to 0.79 for lifetimes and from 0.88 to 0.96 for emissions and a smaller bias with NMB decreasing from -0.04 to 0.02 for lifetimes and from 0.23 to 0.13 for emissions, when comparing with results derived from the $1 \mathrm{~h}$ wind. We have performed the comparison using results based on the weighted averages of 3,6 , and $12 \mathrm{~h}$ wind data as well. The use of wind information prior to the satellite overpass time succeeds in improving the performance of MISATEAM in all these cases (Fig. S4 in the Supplement). Note that the correlation between the inferred and the NU-WRF lifetimes based on $12 \mathrm{~h}$ wind $(R=0.64)$ is not as good as that based on $3 \mathrm{~h}(R=0.74), 6 \mathrm{~h}(R=0.78)$, and $9 \mathrm{~h}(R=0.79)$ wind, which is most likely caused by the inclusion of overnight wind information.

The importance of applying wind information prior to the satellite overpass time should not be overinterpreted. The fitting function Eq. (2) by definition is not capable of describing the $\mathrm{NO}_{2}$ plumes under significantly varying wind directions because such temporal variations are not considered in the fitting function. In this way, wind directions and the results inferred from different wind scenarios are not expected to vary significantly, as far as fits with sufficient quality are yielded. Only 6 out of 26 cities show relative differences larger than $20 \%$ when comparing results derived from $1 \mathrm{~h}$ wind to those derived from $9 \mathrm{~h}$ wind.

We examine a scenario, namely "NU-WRF $\mathrm{NO}_{x} / \mathrm{NO}_{2}$ ", to investigate possible errors from the assumption of a constant 
(a)

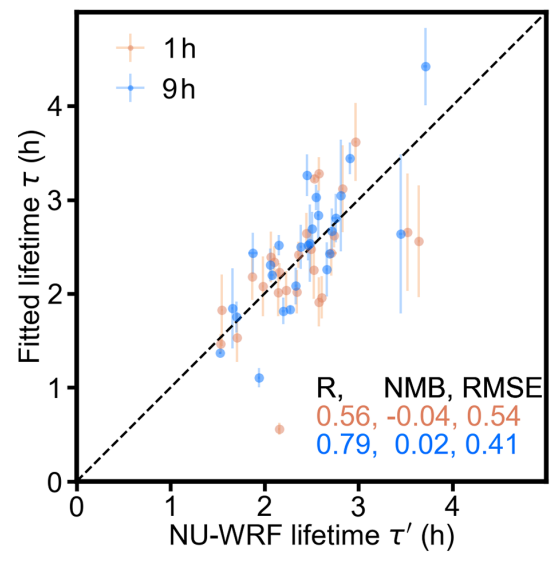

(b)

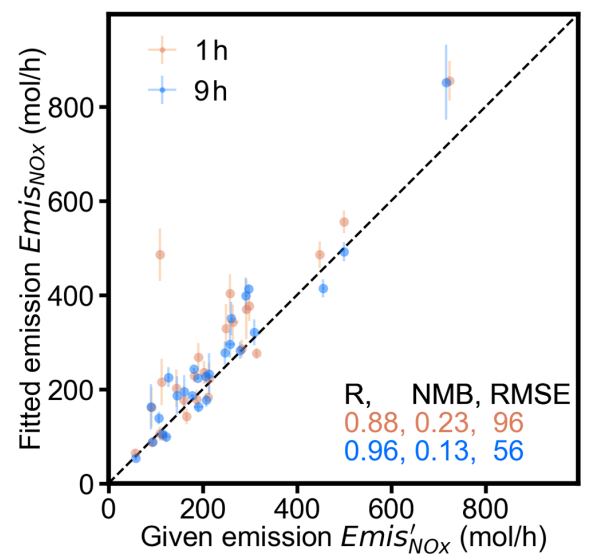

Figure 6. Scatterplots of (a) the fitted $\mathrm{NO}_{x}$ lifetime $\tau$ as compared to the NU-WRF lifetime $\tau^{\prime}$ and (b) the fitted $\mathrm{NO}_{x}$ emissions Emis $\mathrm{NO}_{x}$ as compared to the given emissions Emis ${ }_{\mathrm{NO}_{x}}$. Error bars show the standard error of the fitted results for all available wind directions. Standard error is defined as standard deviation divided by $\sqrt{n}$, with $n$ being the number of available wind directions. The results deriving from the wind fields sampled at 14:00 LT (" $1 \mathrm{~h}$ ") and the weighted average of $9 \mathrm{~h}$ wind fields ("9 h") are displayed by red and blue dots, respectively. The dashed line represents the $1: 1$ line.

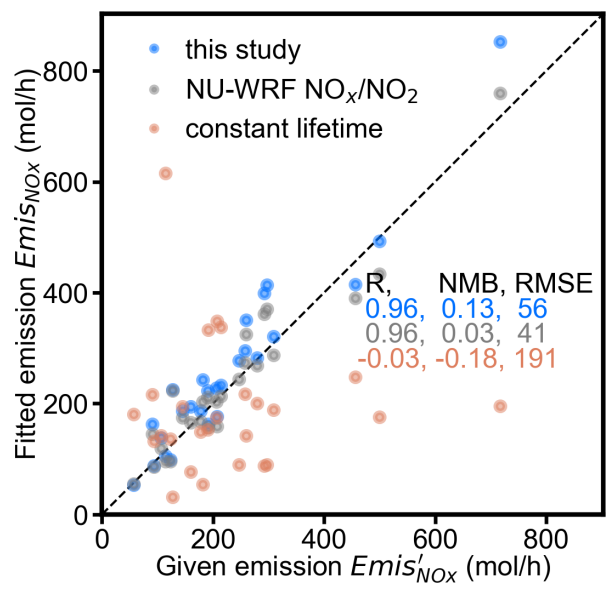

Figure 7. Scatterplot of the fitted total $\mathrm{NO}_{x}$ emissions Emis $_{\mathrm{NO}_{x}}$ as compared to the given total emissions $\mathrm{Emis}_{\mathrm{NO}_{x}}^{\prime}$ under different scenarios. The blue, grey, and red dots represent the scenarios based on the fitted lifetime $\tau$ and a constant $\mathrm{NO}_{x}$ to $\mathrm{NO}_{2}$ ratio of 1.32 ("this study"), the fitted lifetime $\tau$ and the $\mathrm{NO}_{x}$ to $\mathrm{NO}_{2}$ ratio given by the NU-WRF model ("NU-WRF $\mathrm{NO}_{x} / \mathrm{NO}_{2}$ "), and a constant lifetime of $2.5 \mathrm{~h}$ and a constant $\mathrm{NO}_{x}$ to $\mathrm{NO}_{2}$ ratio of 1.32 ("constant lifetime"), respectively. The dashed line represents the $1: 1$ line. Statistics are provided in the inset table.

$R_{\mathrm{NO}_{x}}: \mathrm{NO}_{2}$. We replace $R_{\mathrm{NO}_{x}}: \mathrm{NO}_{2}$ with the ratio of $\mathrm{NO}_{x}$ and $\mathrm{NO}_{2}$ calculated directly from $\mathrm{NO}_{2}$ and NO VCDs per grid cell by NU-WRF outputs and then use MISATEAM for inferring $\mathrm{NO}_{x}$ emissions. Any difference in the inferred emissions compared to the emissions based on the prescribed ratio of 1.32 ("this study") can then be assumed to originate from errors in the assumption of $R_{\mathrm{NO}_{x}}: \mathrm{NO}_{2}$. Figure 7 compares the results using a prescribed ratio (blue dots) with those us- ing NU-WRF $\mathrm{NO}_{x} / \mathrm{NO}_{2}$ (grey dots). The comparison shows nearly the same correlations to the given emissions but a smaller bias for results based on NU-WRF $\mathrm{NO}_{x} / \mathrm{NO}_{2}$, with NMB dropping from 0.13 to almost zero (0.03). The comparison suggests that the influence of changing ratio on derived emissions is limited because its spatial variation is significantly smaller than that of $\mathrm{NO}_{x}$ lifetime and $\mathrm{NO}_{2}$ columns $(\tau$ and $\operatorname{LD}_{\text {calm }}(x)$ in Eq. 1). Considering the investigated cities are located all over the country and have a wide range of geographic features, we conclude that a constant ratio is a reasonable assumption without resulting in significant bias to the derived emissions for typical US cities. The error associated with the assumption is estimated to be $10 \%$, consistent with our previous estimates based on literature reviews (Beirle et al., 2011; Liu et al., 2016b). However, for applications based on geostationary satellites with changing local observation time, the approach using a constant value for $R_{\mathrm{NO}_{x}}: \mathrm{NO}_{2}$ is subject to larger uncertainties arising from the diurnal cycle of $R_{\mathrm{NO}_{x}}: \mathrm{NO}_{2}$ (Han et al., 2011).

We examine an additional scenario, namely "constant lifetime", to show the necessity of deriving lifetimes for individual cities. Instead of individually fitted lifetimes for each city, we use the mean NU-WRF lifetime of all cities $(2.5 \mathrm{~h})$ for the calculation of emissions in the constant lifetime scenario. The emissions correlation drops to -0.03 (Fig. 7), showing that individually fitted lifetimes are critical for this method. The bias is also larger, with RMSE increasing by a factor of 3 compared to results based on the individually fitted lifetimes. This further improves our confidence that the derived variation of the fitted lifetimes carries important information on local variability of the oxidizing capacity of urban plumes. The individual lifetimes are well suited for the determination 
of emissions, suggested by the significantly improved consistency with given emissions.

\subsection{Comparison with previous methods}

We further evaluate MISATEAM by comparing the results with those derived from two previous approaches, including Beirle et al. (2011) and Liu et al. (2016b). The comparison of the technical details between MISATEAM and these two previous approaches is given by Fig. S5 in the Supplement. We apply all three approaches to fit lifetimes and emissions for all 26 cities investigated by this study. Note that we use the $9 \mathrm{~h}$ wind for all approaches for best performance and consistency.

Figure 8a illustrates the comparison for inferring lifetimes. The approach of Beirle et al. (2011) does not predict lifetimes well, with a poor correlation $(R=0.01)$. The correlation improves $(R=0.36)$ when eliminating the data for seven cities with large $(>5 \mathrm{~h})$ or small $(<1 \mathrm{~h})$ fitted lifetimes, assuming the $\mathrm{NO}_{x}$ emission distributions around these cities do not meet the requirements of the Beirle et al. method. The poor correlation is not surprising because by definition the method can only represent a single-point source convolved with a Gaussian function and was not intended to be applied to mixed sources with interfering emissions from nearby cities or industrial areas. For instance, it is capable of giving an accurate estimate for the isolated city of St. Louis in Missouri, with a relative difference of less than $10 \%$ compared to the NU-WRF lifetime. However, for most cities with a polluted background, the fitted lifetimes are biased significantly due to the interference from surroundings. This is consistent with the previous findings for this approach: an additional source at $100 \mathrm{~km}$ with only $10 \%$ of the emissions of the source under investigation causes a lifetime bias of $20 \%$; for an interfering source of the same order as the source of interest, the method fails completely (Liu et al., 2016b). Several studies adopted a plume rotation technique (Pommier et al., 2013; Valin et al., 2013) to advance the approach of Beirle et al. (2011), which is not applicable to mixed sources as well. These techniques rotate $\mathrm{NO}_{2}$ measurements centered over the city center so that $\mathrm{NO}_{2}$ columns under different wind directions are aligned in a common upwind-todownwind direction. This increases the number of observations used for analysis without introducing additional errors for (quasi) point sources, compared with individually analyzing observations by wind directions as done in this study. However, for mixed sources investigated in this study, the use of such rotation techniques may result in significant bias by allocating the $\mathrm{NO}_{2}$ from interfering sources into a ring of elevated $\mathrm{NO}_{2}$ values around the source of the interest and thus amplifying the $\mathrm{NO}_{2}$ signal of the source. An illustration of this amplification can be found in Fig. S2 of Fioletov et al. (2015).

We note that the performance of MISATEAM is also better than that of the approach reported in Liu et al. (2016b), although they share the same concept of using the $\mathrm{NO}_{2}$ patterns observed under calm wind conditions as a proxy for emission patterns instead of assuming a single-point source as in Beirle et al. (2011). It is most likely that Liu et al. (2016b) overfit the model by introducing too many degrees of freedom. As suggested by Fig. 8a, the model function of Liu et al. (2016b) occasionally tries to "explain" changes of scaling factors by a shorter lifetime, resulting in a small $R$ of 0.21. In MISATEAM, we decrease the number of fitting parameters from three in Liu et al. (2016b) to only one (see details in Eq. A4 of Appendix A), which improves the robustness of the fit results.

Emission comparisons in Fig. 8b show better agreement than lifetime comparisons in Fig. 8a for all approaches. MISATEAM-derived emissions show the best consistency with the given emissions. According to mass balance, the magnitude of emissions equals the total mass of $\mathrm{NO}_{x}$ divided by lifetime. In the evaluation for MISATEAM, the given emissions range from 57 to $717 \mathrm{molh}^{-1}$ for all investigated cities, the variation in which is significantly larger than that in lifetimes ranging from 1.5 to $3.7 \mathrm{~h}$. This finding also holds for the other two approaches. The other two approaches can achieve a good correlation with the given emissions by providing reasonable estimates for the magnitude of the total $\mathrm{NO}_{x}$ mass, even though they fail to predict variations in lifetimes between cities. For instance, the results derived from the approach of Liu et al. (2016b) show a small $R$ of 0.21 to the NU-WRF lifetimes but a significantly stronger correlation to the given emissions of 0.94 , which is comparable to that of MISATEAM-derived emissions. But Liu et al. (2016b)-derived emissions are still associated with larger biases arising from the estimates for lifetimes. The values of NMB are 0.13 and -0.21 for emissions derived from MISATEAM and the approach of Liu et al. (2016b), respectively, when comparing against the given emissions. Note that the derived and given emissions from the approach of Liu et al. (2016b) are smaller than the two other approaches but do not indicate a smaller bias. Liu et al. (2016b) only aim to estimate emissions from the city center, considered as a (quasi) point source, instead of all sources in the urban area. In this way, Emis $\mathrm{NO}_{x}$ and $\mathrm{Emis}_{\mathrm{NO}_{x}}^{\prime}$, and thus RMSE, are smaller than those for MISATEAM.

\subsection{Uncertainty analysis}

The good consistency in Sect. 3.1 increases our confidence that the fitted lifetimes and emissions represent the realworld characteristics well. We investigate their uncertainties in this section.

\subsubsection{Sensitivity analysis}

Analogous to Beirle et al. (2011) and Liu et al. (2016b), we investigate the impact of the a priori choice of fit and integration intervals and wind layer height. The dependency of 
(a)

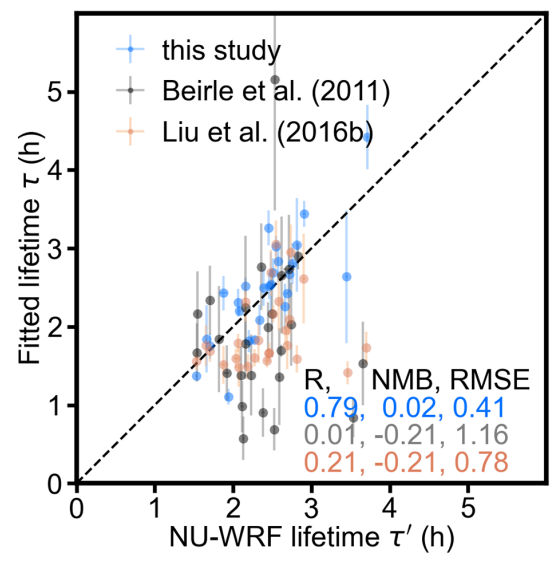

(b)

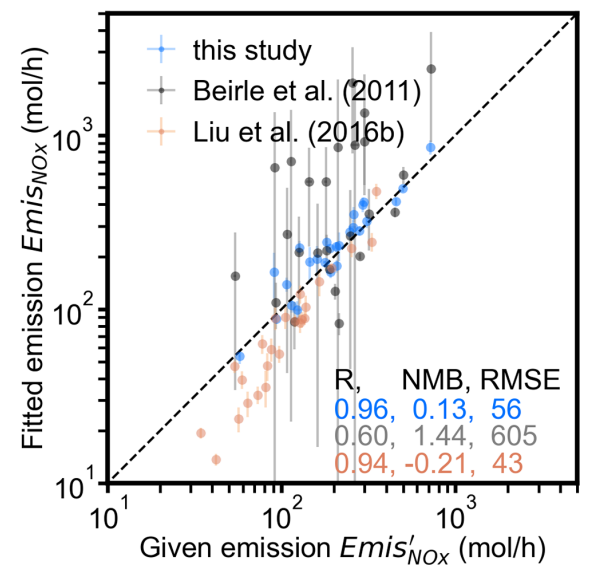

Figure 8. Scatterplots of (a) the fitted $\mathrm{NO}_{x}$ lifetime $\tau$ as compared to the NU-WRF lifetime $\tau^{\prime}$ and (b) the fitted $\mathrm{NO}_{x}$ emissions Emis $\mathrm{NO}_{x}$ as compared to the given emissions Emis $_{\mathrm{NO}_{x}}^{\prime}$. Error bars show the standard error of the fitted results for all available wind directions. Standard error is defined as standard deviation divided by $\sqrt{n}$, with $n$ being the number of available wind directions. The results derived from MISATEAM, the approach of Beirle et al. (2011), and the approach of Liu et al. (2016b) are displayed by blue, grey, and red dots, respectively. The dashed line represents the $1: 1$ line. Note that (b) is plotted on a logarithmic scale.

Table 1. The mean relative change of lifetimes and emissions for different choices of fit and integration intervals and wind fields.

\begin{tabular}{|c|c|c|c|c|c|}
\hline & Interval $_{\text {downwind }}{ }^{\mathrm{a}}+50 \mathrm{~km}$ & Interval $_{\text {upwind }}{ }^{\mathrm{a}}+50 \mathrm{~km}$ & Interval $_{\text {integrate }}{ }^{\mathrm{a}}+50 \mathrm{~km}$ & $500 \mathrm{~m}^{\mathrm{b}}$ & $2000 \mathrm{~m}^{\mathrm{b}}$ \\
\hline Mean $\left[\Delta \tau^{\prime} / \tau^{\prime}\right]$ & $0 \%$ & $9 \%$ & $8 \%$ & $2 \%$ & $-2 \%$ \\
\hline $\operatorname{Mean}[\Delta \tau / \tau]$ & $-2 \%$ & $4 \%$ & $4 \%$ & $16 \%$ & $-11 \%$ \\
\hline Mean $\left[\Delta\right.$ Emis $_{\mathrm{NO}_{x}}^{\prime} /$ Emis $\left._{\mathrm{NO}_{x}}^{\prime}\right]$ & $0 \%$ & $33 \%$ & $36 \%$ & $0 \%$ & $0 \%$ \\
\hline Mean $\left[\Delta\right.$ Emis $_{\mathrm{NO}_{x}} /$ Emis $\left._{\mathrm{NO}_{x}}\right]$ & $2 \%$ & $42 \%$ & $48 \%$ & $-9 \%$ & $13 \%$ \\
\hline $\operatorname{Mean}\left[\Delta\left(\right.\right.$ Emis $_{\mathrm{NO}_{x}} /$ Emis $\left.\left._{\mathrm{NO}_{x}}^{\prime}\right)\right]$ & $3 \%$ & $9 \%$ & $9 \%$ & $-8 \%$ & $12 \%$ \\
\hline
\end{tabular}

${ }^{\mathrm{a}}$ Interval $\mathrm{downwind}=150 \mathrm{~km}$. Interval ${ }_{\text {upwind }}=75 \mathrm{~km}$. Interval ${ }_{\text {integrate }}=150 \mathrm{~km} .{ }^{\mathrm{b}}$ The wind fields are averaged from the surface up to this height.

the fit results for $\tau$ and Emis $_{\mathrm{NO}_{x}}$ on these three choices is tabulated in Table 1.

The fitted lifetimes are generally robust with respect to changes of the fit and integration intervals because the $\mathrm{NO}_{2}$ distribution under calm wind conditions, $\operatorname{LD}_{\text {calm }}(x)$, is a good representation of the emission pattern in any case. An increase of the fit interval in the downwind direction by $50 \mathrm{~km}$ affects the resulting lifetimes by about $-2 \pm 11 \%$. The changes of derived lifetimes are also small when increasing the fit interval in the upwind direction $(4 \pm 12 \%)$ or the integration interval (interval $i+25 \mathrm{~km}$ in Fig. 3; $4 \pm 18 \%$ ) by $50 \mathrm{~km}$. MISATEAM succeeds in avoiding choosing intervals city by city manually, which has been done in previous studies in order to minimize the influence of other nearby sources.

We use the change of the ratio of fitted emissions Emis $_{\mathrm{NO}_{x}}$ to given emissions Emis ${ }_{\mathrm{NO}_{x}}^{\prime}, \Delta\left(\right.$ Emis $_{\mathrm{NO}_{x}} /$ Emis $\left._{\mathrm{NO}_{x}}^{\prime}\right)$, to show the impact of the enlarged fit and integration intervals on emissions. We do not focus on the change of emissions, $\Delta$ Emis $_{\mathrm{NO}_{x}} /$ Emis $_{\mathrm{NO}_{x}}$ because the fitted emissions are expected to be sensitive to the enlarged intervals, which include additional sources and thus more emissions. The fit- ted emissions show an average growth of $48 \%$ associated with extending the integration interval by $50 \mathrm{~km}$ to increase the given emissions by $36 \%$. The rise in emissions is similar to increasing the fit interval in the upwind direction by $50 \mathrm{~km}$ with $33 \%$ for the given emissions and $42 \%$ for the fitted emissions. However, for the scenario of a larger downwind-direction, upwind-direction, and integration interval, the change of the ratio of Emis $_{\mathrm{NO}_{x}}$ to Emis ${ }_{\mathrm{NO}}^{\prime}$ is rather small, which is $3 \%, 9 \%$, and $9 \%$ on average, respectively; the fitted emissions show good consistency with the given emissions, reporting correlation coefficients of $0.95,0.92$, and 0.86 , respectively. It is interesting to note that the fitted emissions are rather insensitive to the extension of the fit interval in downwind direction. Neither the given nor the fitted emissions are significantly changed by increasing the downwind-direction interval from 150 to $200 \mathrm{~km}$. It suggests that we succeed in capturing the complete downwind plume and reaching the background areas by the default setting of $150 \mathrm{~km}$ for the investigated cities in this study.

Uncertainties associated with the choice of top wind layer height (e.g., 500, 1000, or $2000 \mathrm{~m}$ ) are relatively small. The resulting lifetimes and emissions change about $16 \%$ and 
$-9 \%$ on average when averaging the wind fields from the surface to up to $500 \mathrm{~m}$. The average changes are $-11 \%$ and $13 \%$ for inferring lifetimes and emissions, respectively, when adopting the wind layer height of $2000 \mathrm{~m}$. This is consistent with the findings in the previous studies (e.g., Beirle et al., 2011 and Liu et al., 2016b).

We also apply MISATEAM to year-round $\mathrm{NO}_{2}$ data to investigate the impact of including winter data on the performance of the method. We keep default settings of MISATEAM as described in Sect. 2.2 for the fit. As expected, the fitted results differ more significantly from given values compared with results based on using only non-winter data. The bias is larger with NMB changing from 0.02 to -0.14 for lifetimes and from 0.13 to 0.27 for emissions. This indicates that MISATEAM, most likely its inherent steady-wind assumption, is less accurate during the winter season with longer $\mathrm{NO}_{x}$ lifetimes.

\subsubsection{Uncertainty quantification}

We calculate the uncertainties of inferred results based on the fitting metrics (Figs. 6 and 7) and the dependencies on the a priori settings as investigated in the above sensitivity studies. We attribute uncertainties of $15 \%$ and $20 \%$ to the derived lifetimes and emissions, respectively, based on the mean of relative differences for all 26 cities (14\% for lifetimes and $21 \%$ for emissions). The derived emissions have higher uncertainties arising from uncertainty in the $\mathrm{NO}_{x}$ to $\mathrm{NO}_{2}$ scaling factor. The derived emissions in terms of $\mathrm{NO}_{2}$ are upscaled to $\mathrm{NO}_{x}$ based on a constant $\mathrm{NO}_{x} / \mathrm{NO}_{2}$ ratio of 1.32 , representing typical urban conditions at noon (Seinfeld and Pandis, 2006). Since MISATEAM aims to provide estimates for cloud-free satellite observations at the overpass time close to noon of non-winter seasons, and it focuses on polluted regions with generally high tropospheric ozone, this value is reasonably accurate. However, the $\mathrm{NO}_{x} / \mathrm{NO}_{2}$ ratio might vary locally. NU-WRF reports $1.4 \pm 0.1$ with a range of 1.2-1.6. The overall impact of variations in this ratio is shown to be relatively small (see Sect. 3.1).

We can identify additional uncertainties that would be present when applying MISATEAM to "real" data instead of synthetic data. The uncertainty of satellite $\mathrm{NO}_{2}$ observations propagates into the uncertainty of emissions. The uncertainty of satellite $\mathrm{NO}_{2}$ observations has less impact on the lifetime estimation and only results in errors for lifetimes when satellite observations have systematic errors depending on the distance from the source. The total uncertainty of $\mathrm{NO}_{2}$ VCDs results from uncertainties in the spectral fit in the retrieval, the stratospheric and tropospheric separation, and the tropospheric air mass factor (AMF). In the model function of MISATEAM, a possible bias associated with the stratospheric and tropospheric separation is eliminated by use of the background term $b$. The uncertainty in the spectral fit in the retrieval is rather small compared to that associated with AMF (Boersma et al., 2007). We estimated the overall uncertainty primarily arising from the uncertainty in the tropospheric AMF is about $25 \%$ based on validation of TROPOMI $\mathrm{NO}_{2}$ products with ground-based measurements (e.g., Griffin et al., 2019; Ialongo et al., 2020; Zhao et al., 2020). Since the random uncertainty of the tropospheric $\mathrm{NO}_{2}$ observations could be suppressed due to the consideration of long-term means, this estimate may be conservative.

The presence of clouds is an additional source of uncertainties. We are required to exclude satellite observations with significant cloud fractions in the instrument's field of view. For TROPOMI $\mathrm{NO}_{2}$ products, we usually remove data with cloud radiance fraction $\geq 0.5$. A bias is observed in $\mathrm{NO}_{2}$ $\mathrm{VCD}$ averages as a result of removing the data during cloudy conditions (Geddes et al., 2012). The bias is associated with changing photochemistry, meteorology, and pollutant transport, which may also have impacts on the $\mathrm{NO}_{x} / \mathrm{NO}_{2}$ ratio and $\mathrm{NO}_{x}$ lifetime. $\mathrm{NO}_{x}$ lifetime on a sunny day with valid satellite observations will likely be shorter than that on a cloudy day since faster photolysis rates are expected for $\mathrm{NO}_{x}$ reactions on sunny days. The magnitude of a bias is expected to vary from city to city. We calculate the fraction of cloudy scenes to total scenes over the fit domain of individual cities based on TROPOMI $\mathrm{NO}_{2}$ products from April through September, 2020. The fractions range from $16 \%-56 \%$ for the considered cities. For cities with heavy cloud cover, like New York, Philadelphia, and Washington D.C., with a fraction $>50 \%$, the impact associated with cloud selection criteria is expected to be larger than cities with more clear sky. We estimated an uncertainty of $10 \%$ arising from cloud selection criteria based on the evaluation performed at urban sites (Geddes et al., 2012).

Additionally, the accuracy of wind fields contributes to the uncertainties of both lifetimes and emissions. It can affect the sorting of the $\mathrm{NO}_{2} \mathrm{VCDs}$ according to wind direction as well as the conversion of the downwind decay from a function of distance into a function of time in Eq. (2). We estimate the uncertainties associated with the wind data to be approximately $30 \%$ based on the comparison of wind information between the reanalysis product and sounding measurements (see Table S3 in Liu et al., 2016b).

We define total uncertainties of the resulting lifetimes and emissions as the root of the quadratic sum of the abovementioned error contributions that are assumed to be independent. We estimated that total uncertainties of $\mathrm{NO}_{x}$ lifetime and emissions for a US city are $43 \%$ and $45 \%$, respectively.

\section{Conclusions and future work}

In this work we developed a CTM-independent approach, MISATEAM, to infer $\mathrm{NO}_{x}$ lifetimes and emissions from satellite $\mathrm{NO}_{2}$ observations. As in Liu et al. (2016b), MISATEAM is developed for sources with polluted backgrounds. It adopts the approach of using $\mathrm{NO}_{2}$ spatial patterns under 
calm wind conditions as a proxy for the spatial patterns of emission sources to account for interferences from neighboring strong sources. MISATEAM improves upon Liu et al. (2016b) by advancing the fitting function to reduce the number of parameters and to provide estimations of $\mathrm{NO}_{x}$ lifetimes and emissions simultaneously.

We applied MISATEAM to synthetic tropospheric $\mathrm{NO}_{2}$ VCDs over the continental United States provided by a NU-WRF high-resolution model simulation. We found that our new method for determining $\mathrm{NO}_{x}$ lifetimes and emissions was applicable to 26 cities. The derived results were generally in good agreement with the NU-WRF given values. In existing studies, wind fields sampled simultaneously with satellite observations were used to drive the CTMindependent approach. We investigated the impact of temporal variations in winds on fitted results and found the use of wind data prior to the satellite overpass time improves performance of our approach. $R$ between inferred and NUWRF lifetimes increased from 0.56 to 0.79 and for emissions increased from 0.88 to 0.96 when comparing results based on 1 and $9 \mathrm{~h}$ winds, respectively. The comparison between MISATEAM and the approaches of Beirle et al. (2011) and Liu et al. (2016b) suggests that MISATEAM is more suitable for non-isolated sources, particularly for lifetime estimation. Lifetimes inferred from the previous approaches showed rather weak correlations with respect to NU-WRF lifetimes ( 0.01 for Beirle et al., 2011 and 0.21 for Liu et al., $2016 b)$ as compared with those from MISATEAM (0.79).

We plan to apply MISATEAM to observations from TROPOMI and geostationary satellite instruments including the Korean Geostationary Environmental Monitoring Spectrometer (GEMS; Kim et al., 2012), NASA Tropospheric Emissions: Monitoring of Pollution (TEMPO; Chance et al., 2012), and ESA Sentinel-4 (Ingmann et al., 2012). These instruments have spatial resolutions similar to the NU-WRF simulation $(4 \mathrm{~km})$ used in this study. For applications based on geostationary satellites with local observation time outside of the early afternoon time frame, additional investigation about the impact of the diurnal cycle of $\mathrm{NO}_{2}$ lifetime is required, since MISATEAM is expected to have a larger uncertainty when the lifetime is longer. We estimate that uncertainties in $\mathrm{NO}_{x}$ lifetime and emissions arising from MISATEAM are approximately $15 \%$ and $20 \%$, respectively, for typical (US) cities. Additional uncertainties are associated with wind errors in the reanalysis dataset as well as errors in the satellite $\mathrm{NO}_{2}$ retrievals, increasing the total uncertainties of $\mathrm{NO}_{x}$ lifetime and emissions to $43 \%$ and $45 \%$, respectively. The general low bias of $\mathrm{NO}_{2}$ tropospheric VCDs from TROPOMI for polluted sites (Verhoelst et al. 2021) is directly transferred into the inferred $\mathrm{NO}_{x}$ emissions if no correction is performed. We will attempt to reconcile bottom-up and satellite-derived urban emissions to generate a merged inventory (e.g., Liu et al., 2018) to provide timely $\mathrm{NO}_{x}$ emissions estimation for air quality and climate modeling communities.

\section{Appendix A: Derivation of the model function $f(x)$}

We derive Eq. (1) based on the continuity equation for a steady state, following Eqs. (A1) and (A2) given by

$E(x)=S(x)+D(x)$,
$S(x)=\frac{R_{\mathrm{NO}_{x}}: \mathrm{NO}_{2} \cdot \mathrm{LD}(x)}{\tau}$,

where $E(s), S(x)$, and $D(x)$ represent the line densities of $\mathrm{NO}_{x}$ emission, sink, and divergence, respectively. As the $\mathrm{NO}_{x}$ sinks are dominated by the chemical loss due to reaction of $\mathrm{NO}_{2}$ with $\mathrm{OH}$ at the local overpass time of TROPOMI (13:30 LT), sink $S(x)$ can be described by a first-order time constant $\tau$ and thus is proportional to the $\mathrm{NO}_{2}$ line density $\mathrm{LD}(x)$ itself as shown in Eq. (A2). Beirle et al. (2019) provided further details.

We use $\mathrm{NO}_{2}$ line densities under calm wind conditions, $\mathrm{LD}_{\text {calm }}(x)$, to simplify Eqs. (A1) and (A2). In principle, there is no $\mathrm{NO}_{x}$ transport under perfect calm wind conditions (i.e., divergence $D(x)$ is zero), and thus the emission $E(x)$ equals the sink $S(x)$ given by $\frac{R_{\mathrm{NO}_{x}: \mathrm{NO}_{2}} \cdot \mathrm{LD}_{\text {calm }}(x)}{\tau}$. However, we use the threshold of $2 \mathrm{~m} \mathrm{~s}^{-1}$, instead of $0 \mathrm{~m} \mathrm{~s}^{-1}$, as the criterion for calm wind to get a good compromise between sufficient sample sizes for the calculation of line densities under both calm conditions and windy conditions. In order to account for the error associated with this criterion and possible systemic differences between windy and calm wind conditions (e.g., cloud conditions, vertical profiles, or lifetimes), and to account for the upper tropospheric background column which is not driven by local emissions, we introduce a constant background $b$ in the fitting function, as given by Eq. (A3).

$E(x)=S(x)=\frac{R_{\mathrm{NO}_{x}: \mathrm{NO}_{2}} \cdot\left[\mathrm{LD}_{\text {calm }}(x)-b\right]}{\tau}$

We derive Eq. (2) following the concept proposed by Liu et al. (2016b). We use $\operatorname{LD}_{\text {calm }}(x)$ as a proxy for emissions instead of assuming a single-point source as in previous studies (e.g., Beirle et al., 2011; Laughner et al., 2019). The $\mathrm{NO}_{2}$ line density without considering the chemical decay is given by $\frac{E(x)}{R_{\mathrm{NO}_{x}}: \mathrm{NO}_{2} \cdot w}$ based on a Gaussian plume model. This formulation is different from the model function $f(x)$ ' originally proposed by Liu et al. (2016b), which was given by

$f(x)^{\prime}=a \cdot \operatorname{LD}_{\text {calm }}(x) * e^{-\frac{x}{w \cdot \tau}}+b$.

We replaced one fitting parameter, the scaling factor $a$ in $f(x)^{\prime}$, with variables that have physical meanings in the new model function $f(x)$. The new formulation was shown to improve the model performance in Sect. 3.2. We then convolved $\frac{E(x)}{R_{\mathrm{NO}_{x}: \mathrm{NO}_{2} \cdot w}}$ with an exponential function $e^{-\frac{x}{w \cdot \tau}}$ describing the chemical decay to form the new model function $f(x)$ ), implicitly assuming a constant effective lifetime $\tau$. 
Data availability. The NU-WRF model outputs are available upon request from Zhining Tao (zhining.tao@ nasa.gov). Additional data related to this paper may be requested from the corresponding author.

Supplement. The supplement related to this article is available online at: https://doi.org/10.5194/acp-22-1333-2022-supplement.

Author contributions. FL, JJ, and SB provided conceptualization and methodology, ZT performed model simulation, FL and YY performed formal analysis, FL prepared the original draft, and all authors reviewed and edited the finalized draft. FL prepared visualization, and FL and JJ provided supervision, project administration, and funding acquisition.

Competing interests. At least one of the (co-)authors is a member of the editorial board of Atmospheric Chemistry and Physics. The peer-review process was guided by an independent editor, and the authors also have no other competing interests to declare.

Disclaimer. Publisher's note: Copernicus Publications remains neutral with regard to jurisdictional claims in published maps and institutional affiliations.

Acknowledgements. Resources supporting this work were provided by the NASA High-End Computing (HEC) Program through the NASA Center for Climate Simulation (NCCS) at the Goddard Space Flight Center. We thank two anonymous reviewers for helpful comments.

Financial support. This research has been supported by NASA through the Aura project data analysis program and through the Atmospheric Composition Modeling and Analysis Program (ACMAP) (grant no. 80NSSC19K0980).

Review statement. This paper was edited by Aijun Ding and reviewed by two anonymous referees.

\section{References}

Beirle, S., Boersma, K. F., Platt, U., Lawrence, M. G., and Wagner, T.: Megacity emissions and lifetimes of nitrogen oxides probed from space, Science, 333, 1737-1739, https://doi.org/10.1126/science.1207824, 2011.

Beirle, S., Borger, C., Dörner, S., Li, A., Hu, Z., Liu, F., Wang, Y., and Wagner, T.: Pinpointing nitrogen oxide emissions from space, Sci. Adv., 5, eaax9800, https://doi.org/10.1126/sciadv.aax9800, 2019.

Berge, E., Huang, H.-C., Chang, J., and Liu, T.-H.: A study of the importance of initial conditions for photochemi- cal oxidant modeling, J. Geophys. Res., 106, 1347-1363, https://doi.org/10.1029/2000jd900227, 2001.

Boersma, K. F., Eskes, H. J., Veefkind, J. P., Brinksma, E. J., van der A, R. J., Sneep, M., van den Oord, G. H. J., Levelt, P. F., Stammes, P., Gleason, J. F., and Bucsela, E. J.: Near-real time retrieval of tropospheric $\mathrm{NO}_{2}$ from OMI, Atmos. Chem. Phys., 7, 2103-2118, https://doi.org/10.5194/acp-7-2103-2007, 2007.

Butler, T. M., Lawrence, M. G., Gurjar, B. R., van Aardenne, J., Schultz, M., and Lelieveld, J.: The representation of emissions from megacities in global emission inventories, Atmos. Environ., 42, 703-719, https://doi.org/10.1016/j.atmosenv.2007.09.060, 2008.

Chance, K., Lui, X., Suleiman, R. M., Flittner, D. E., and Janz, S. J.: Tropospheric Emissions: monitoring of Pollution (TEMPO), presented at the 2012 AGU Fall Meeting, San Francisco, USA, 3-7 December 2012, A31B-0020, 2012.

Chin, M., Ginoux, P., Kinne, S., Torres, O., Holben, B. N., Duncan, B. N., Martin, R. V., Logan, J. A., Higurashi, A., and Nakajima, T.: Tropospheric aerosol optical thickness from the GOCART model and comparisons with satellite and sun photometer measurements, J. Atmos. Sci., 59, 461-483, https://doi.org/10.1175/15200469(2002)059<0461:TAOTFT>2.0.CO;2, 2002.

Chin, M., Diehl, T., Ginoux, P., and Malm, W.: Intercontinental transport of pollution and dust aerosols: implications for regional air quality, Atmos. Chem. Phys., 7, 5501-5517, https://doi.org/10.5194/acp-7-5501-2007, 2007.

Choi, S., Lamsal, L. N., Follette-Cook, M., Joiner, J., Krotkov, N. A., Swartz, W. H., Pickering, K. E., Loughner, C. P., Appel, W., Pfister, G., Saide, P. E., Cohen, R. C., Weinheimer, A. J., and Herman, J. R.: Assessment of $\mathrm{NO}_{2}$ observations during DISCOVERAQ and KORUS-AQ field campaigns, Atmos. Meas. Tech., 13, 2523-2546, https://doi.org/10.5194/amt-13-2523-2020, 2020.

Chou, M.-D. and Suarez, M. J.: A solar radiation parameterization for atmospheric studies, NASA Tech. Rep. NASA/TM-199910460, NASA Goddard Space Flight Center, Greenbelt, MD, USA, Vol. 15, 38 pp., 1999.

Crippa, M., Guizzardi, D., Muntean, M., Schaaf, E., Dentener, F., van Aardenne, J. A., Monni, S., Doering, U., Olivier, J. G. J., Pagliari, V., and Janssens-Maenhout, G.: Gridded emissions of air pollutants for the period 1970-2012 within EDGAR v4.3.2, Earth Syst. Sci. Data, 10, 1987-2013, https://doi.org/10.5194/essd-10-1987-2018, 2018.

de Foy, B., Wilkins, J. L., Lu, Z., Streets, D. G., and Duncan, B. N.: Model evaluation of methods for estimating surface emissions and chemical lifetimes from satellite data, Atmos. Environ., 98, 66-77, https://doi.org/10.1016/j.atmosenv.2014.08.051, 2014.

de Foy, B., Lu, Z., Streets, D. G., Lamsal, L. N., and Duncan, B. N.: Estimates of power plant $\mathrm{NO}_{x}$ emissions and lifetimes from $\mathrm{OMI} \mathrm{NO}_{2}$ satellite retrievals, Atmos. Environ., 116, 1-11, https://doi.org/10.1016/j.atmosenv.2015.05.056, 2015.

Ding, J., van der A, R. J., Mijling, B., and Levelt, P. F.: Space-based $\mathrm{NO}_{x}$ emission estimates over remote regions improved in DECSO, Atmos. Meas. Tech., 10, 925-938, https://doi.org/10.5194/amt-10-925-2017, 2017.

Fioletov, V. E., McLinden, C. A., Krotkov, N., and Li, C.: Lifetimes and emissions of $\mathrm{SO}_{2}$ from point sources estimated from OMI, Geophys. Res. Lett., 42, 1969-1976, https://doi.org/10.1002/2015GL063148, 2015. 
Gelaro, R., McCarty, W., Suárez, M. J., Todling, R., Molod, A., Takacs, L., Randles, C. A., Darmenov, A., Bosilovich, M. G., Reichle, R., Wargan, K., Coy, L., Cullather, R., Draper, C., Akella, S., Buchard, V., Conaty, A., Silva, A. M. da, Gu, W., Kim, G.K., Koster, R., Lucchesi, R., Merkova, D., Nielsen, J. E., Partyka, G., Pawson, S., Putman, W., Rienecker, M., Schubert, S. D., Sienkiewicz, M., and Zhao, B.: The Modern-Era Retrospective analysis for Research and Applications, version 2 (MERRA2), J. Climate, 30, 5419-5454, https://doi.org/10.1175/JCLI-D16-0758.1, 2017.

Geddes, J. A., Murphy, J. G., O’Brien, J. M., and Celarier, E. A.: Biases in long-term $\mathrm{NO}_{2}$ averages inferred from satellite observations due to cloud selection criteria, Remote Sens. Environ., 124, 210-216, https://doi.org/10.1016/j.rse.2012.05.008, 2012.

Ginoux, P., Chin, M., Tegen, I., Prospero, J. M., Holben, B., Dubovik, O., and Lin, S.-J.: Sources and distributions of dust aerosols simulated with the GOCART model, J. Geophys. Res., 106, 20255-20273, https://doi.org/10.1029/2000JD000053, 2001.

Goldberg, D. L., Lu, Z., Streets, D. G., de Foy, B., Griffin, D., McLinden, C. A., Lamsal, L. N., Krotkov, N. A., and Eskes, H.: Enhanced capabilities of TROPOMI $\mathrm{NO}_{2}$ : Estimating $\mathrm{NO}_{x}$ from North American cities and power plants, Environ. Sci. Technol., 53, 12594-12601, https://doi.org/10.1021/acs.est.9b04488, 2019.

Gong, S. L.: A parameterization of sea-salt aerosol source function for sub- and super-micron particles, Global. Biogeochem. Cy., 17, 1097, https://doi.org/10.1029/2003GB002079, 2003.

Grell, G. A., Peckham, S. E., Schmitz, R., McKeen, S. A., Frost, G., Skamarock, W. C., and Eder, B.: Fully coupled "online" chemistry within the WRF model, Atmos. Environ., 39, 6957-6975, https://doi.org/10.1016/j.atmosenv.2005.04.027, 2005.

Griffin, D., Zhao, X., McLinden, C. A., Boersma, F., Bourassa, A., Dammers, E., Degenstein, D., Eskes, H., Fehr, L., Fioletov, V., Hayden, K., Kharol, S. K., Li, S.-M., Makar, P., Martin, R. V., Mihele, C., Mittermeier, R. L., Krotkov, N., Sneep, M., Lamsal, L. N., Linden, M. ter, Geffen, J. van, Veefkind, P., and Wolde, M.: High-resolution mapping of nitrogen dioxide with TROPOMI: First results and validation over the Canadian oil sands, Geophys. Res. Lett., 46, 1049-1060, https://doi.org/10.1029/2018g1081095, 2019.

Gross, A. and Stockwell, W. R.: Comparison of the EMEP, RADM2 and RACM mechanisms, J. Atmos. Chem., 44, 151170, https://doi.org/10.1023/a:1022483412112, 2003.

Guenther, A., Karl, T., Harley, P., Wiedinmyer, C., Palmer, P. I., and Geron, C.: Estimates of global terrestrial isoprene emissions using MEGAN (Model of Emissions of Gases and Aerosols from Nature), Atmos. Chem. Phys., 6, 3181-3210, https://doi.org/10.5194/acp-6-3181-2006, 2006.

Han, S., Bian, H., Feng, Y., Liu, A., Li, X., Zeng, F. and Zhang, X.: Analysis of the Relationship between $\mathrm{O}_{3}$, NO and $\mathrm{NO}_{2}$ in Tianjin, China, Aerosol Air Qual. Res., 11, 128-139, https://doi.org/10.4209/aaqr.2010.07.0055, 2011.

Henze, D. K., Hakami, A., and Seinfeld, J. H.: Development of the adjoint of GEOS-Chem, Atmos. Chem. Phys., 7, 2413-2433, https://doi.org/10.5194/acp-7-2413-2007, 2007.

Henze, D. K., Seinfeld, J. H., and Shindell, D. T.: Inverse modeling and mapping US air quality influences of inorganic $\mathrm{PM}_{2.5}$ precursor emissions using the adjoint of GEOS-Chem, Atmos.
Chem. Phys., 9, 5877-5903, https://doi.org/10.5194/acp-9-58772009, 2009.

Ialongo, I., Virta, H., Eskes, H., Hovila, J., and Douros, J.: Comparison of TROPOMI/Sentinel-5 Precursor $\mathrm{NO}_{2}$ observations with ground-based measurements in Helsinki, Atmos. Meas. Tech., 13, 205-218, https://doi.org/10.5194/amt-13-205-2020, 2020.

Ingmann, P., Veihelmann, B., Langen, J., Lamarre, D., Stark, H., and Courrèges-Lacoste, G. B.: Requirements for the GMES atmosphere service and ESA's implementation concept: Sentinels-4/-5 and -5p, Remote Sens. Environ., 120, 58-69, https://doi.org/10.1016/j.rse.2012.01.023, 2012.

Kim, D., Chin, M., Kemp, E. M., Tao, Z., Peters-Lidard, C. D., and Ginoux, P.: Development of high-resolution dynamic dust source function - A case study with a strong dust storm in a regional model, Atmos. Environ. Oxf. Engl. 1994, 159, 11-25, https://doi.org/10.1016/j.atmosenv.2017.03.045, 2017.

Kim, J.: GEMS (Geostationary Environment Monitoring Spectrometer) onboard the GeoKOMPSAT to monitor air quality in high temporal and spatial resolution over Asia-Pacific Region, Geophys. Res. Abstr., EGU2012-4051, EGU General Assembly 2012, Vienna, Austria, 2012.

Kim, S. W., Heckel, A., Frost, G. J., Richter, A., Gleason, J., Burrows, J. P., McKeen, S., Hsie, E. Y., Granier, C., and Trainer, $\mathrm{M}$.: $\mathrm{NO}_{2}$ columns in the western United States observed from space and simulated by a regional chemistry model and their implications for $\mathrm{NO}_{x}$ emissions, J. Geophys. Res., 114, D11301, https://doi.org/10.1029/2008jd011343, 2009.

Kumar, S. V., Peters-Lidard, C. D., Tian, Y., Houser, P. R., Geiger, J., Olden, S., Lighty, L., Eastman, J. L., Doty, B., Dirmeyer, P., Adams, J., Mitchell, K., Wood, E. F., and Sheffield, J.: Land information system: An interoperable framework for high resolution land surface modeling, Environ. Model. Softw., 21, 14021415, https://doi.org/10.1016/j.envsoft.2005.07.004, 2006.

Lamarque, J.-F., Emmons, L. K., Hess, P. G., Kinnison, D. E., Tilmes, S., Vitt, F., Heald, C. L., Holland, E. A., Lauritzen, P. H., Neu, J., Orlando, J. J., Rasch, P. J., and Tyndall, G. K.: CAM-chem: description and evaluation of interactive atmospheric chemistry in the Community Earth System Model, Geosci. Model Dev., 5, 369-411, https://doi.org/10.5194/gmd-5369-2012, 2012.

Lamsal, L. N., Martin, R. V., Padmanabhan, A., van Donkelaar, A., Zhang, Q., Sioris, C. E., Chance, K., Kurosu, T. P., and Newchurch, M. J.: Application of satellite observations for timely updates to global anthropogenic $\mathrm{NO}_{x}$ emission inventories, Geophys. Res. Lett., 38, L05810, https://doi.org/10.1029/2010gl046476, 2011.

Lange, K., Richter, A., and Burrows, J. P.: Variability of nitrogen oxide emission fluxes and lifetimes estimated from Sentinel-5P TROPOMI observations, Atmos. Chem. Phys. Discuss. [preprint], https://doi.org/10.5194/acp-2021-273, in review, 2021.

Laughner, J. L. and Cohen, R. C.: Direct observation of changing $\mathrm{NO}_{x}$ lifetime in North American cities, Science, 366, 723-727, https://doi.org/10.1126/science.aax6832, 2019.

Leue, C., Wenig, M., Wagner, T., Klimm, O., Platt, U., and Jähne, B.: Quantitative analysis of $\mathrm{NO}_{x}$ emissions from Global Ozone Monitoring Experiment satellite image sequences, J. Geophys. Res., 106, 5493-5505, https://doi.org/10.1029/2000JD900572, 2001. 
Levelt, P. F., van den Oord, G. H. J., Dobber, M. R., Malkki, A., Huib, V., Johan de, V., Stammes, P., Lundell, J. O. V., and Saari, H.: The ozone monitoring instrument, IEEE T. Geosci. Remote Sens., 44, 1093-1101, 2006.

Levelt, P. F., Joiner, J., Tamminen, J., Veefkind, J. P., Bhartia, P. K., Stein Zweers, D. C., Duncan, B. N., Streets, D. G., Eskes, H., van der A, R., McLinden, C., Fioletov, V., Carn, S., de Laat, J., DeLand, M., Marchenko, S., McPeters, R., Ziemke, J., Fu, D., Liu, X., Pickering, K., Apituley, A., González Abad, G., Arola, A., Boersma, F., Chan Miller, C., Chance, K., de Graaf, M., Hakkarainen, J., Hassinen, S., Ialongo, I., Kleipool, Q., Krotkov, N., Li, C., Lamsal, L., Newman, P., Nowlan, C., Suleiman, R., Tilstra, L. G., Torres, O., Wang, H., and Wargan, K.: The Ozone Monitoring Instrument: overview of 14 years in space, Atmos. Chem. Phys., 18, 5699-5745, https://doi.org/10.5194/acp18-5699-2018, 2018.

Liu, F., Zhang, Q., A, R. J. van der, Zheng, B., Tong, D., Yan, L., Zheng, Y., and He, K.: Recent reduction in $\mathrm{NO}_{x}$ emissions over China: synthesis of satellite observations and emission inventories, Environ. Res. Lett., 11, 114002, https://doi.org/10.1088/1748-9326/11/11/114002, 2016a.

Liu, F., Beirle, S., Zhang, Q., Dörner, S., He, K., and Wagner, T.: $\mathrm{NO}_{x}$ lifetimes and emissions of cities and power plants in polluted background estimated by satellite observations, Atmos. Chem. Phys., 16, 5283-5298, https://doi.org/10.5194/acp16-5283-2016, 2016b.

Liu, F., Beirle, S., Zhang, Q., van der A, R. J., Zheng, B., Tong, D., and He, K.: $\mathrm{NO}_{x}$ emission trends over Chinese cities estimated from OMI observations during 2005 to 2015, Atmos. Chem. Phys., 17, 9261-9275, https://doi.org/10.5194/acp-179261-2017, 2017.

Liu, F., Choi, S., Li, C., Fioletov, V. E., McLinden, C. A., Joiner, J., Krotkov, N. A., Bian, H., Janssens-Maenhout, G., Darmenov, A. S., and da Silva, A. M.: A new global anthropogenic $\mathrm{SO}_{2}$ emission inventory for the last decade: a mosaic of satellite-derived and bottom-up emissions, Atmos. Chem. Phys., 18, 1657116586, https://doi.org/10.5194/acp-18-16571-2018, 2018.

Liu, F., Duncan, B. N., Krotkov, N. A., Lamsal, L. N., Beirle, S., Griffin, D., McLinden, C. A., Goldberg, D. L., and Lu, Z.: A methodology to constrain carbon dioxide emissions from coal-fired power plants using satellite observations of coemitted nitrogen dioxide, Atmos. Chem. Phys., 20, 99-116, https://doi.org/10.5194/acp-20-99-2020, 2020.

Lorente, A., Boersma, K. F., Eskes, H. J., Veefkind, J. P., van Geffen, J. H. G. M., de Zeeuw, M. B., Denier van der Gon, H. A. C., Beirle, S., and Krol, M. C.: Quantification of nitrogen oxides emissions from build-up of pollution over Paris with TROPOMI, Sci. Rep.-UK, 9, 20033, https://doi.org/10.1038/s41598-01956428-5, 2019.

Lu, Z., Streets, D. G., de Foy, B., Lamsal, L. N., Duncan, B. N., and Xing, J.: Emissions of nitrogen oxides from US urban areas: estimation from Ozone Monitoring Instrument retrievals for 2005-2014, Atmos. Chem. Phys., 15, 10367-10383, https://doi.org/10.5194/acp-15-10367-2015, 2015.

Martin, R. V., Jacob, D. J., Chance, K., Kurosu, T. P., Palmer, P. I., and Evans, M. J.: Global inventory of nitrogen oxide emissions constrained by space-based observations of $\mathrm{NO}_{2}$ columns, J. Geophys. Res., 108, 4537, https://doi.org/10.1029/2003jd003453, 2003.
McLinden, C. A., Fioletov, V., Shephard, M. W., Krotkov, N., Li, C., Martin, R. V., Moran, M. D., and Joiner, J.: Space-based detection of missing sulfur dioxide sources of global air pollution, Nat. Geosci, 9, 496-500, 2016.

Michalakes, J., Chen, S., Dudhia, J., Hart, L., Klemp, J., Middlecoff, J., and Skamarock, W.: Development of a nextgeneration regional weather research and forecast model, in: Developments in Teracomputing, edited by: Zwieflhofer, W. and Kreitz, N., World Scientific, Reading, UK, 269-276, https://doi.org/10.1142/9789812799685_0024, 2001.

Miyazaki, K., Eskes, H., Sudo, K., Boersma, K. F., Bowman, K., and Kanaya, Y.: Decadal changes in global surface $\mathrm{NO}_{x}$ emissions from multi-constituent satellite data assimilation, Atmos. Chem. Phys., 17, 807-837, https://doi.org/10.5194/acp-17-8072017, 2017.

Pan, L. L. and Munchak, L. A.: Relationship of cloud top to the tropopause and jet structure from CALIPSO data, J. Geophys. Res., 116, D12201, https://doi.org/10.1029/2010JD015462, 2011.

Peters-Lidard, C. D., Houser, P. R., Tian, Y., Kumar, S. V., Geiger, J., Olden, S., Lighty, L., Doty, B., Dirmeyer, P., Adams, J., Mitchell, K., Wood, E. F., and Sheffield, J.: Highperformance earth system modeling with NASA/GSFC's land information system, Innov. Syst. Softw. Eng., 3, 157-165, https://doi.org/10.1007/s11334-007-0028-x, 2007.

Peters-Lidard, C. D., Kemp, E. M., Matsui, T., Santanello, J. A., Kumar, S. V., Jacob, J. P., Clune, T., Tao, W.-K., Chin, M., Hou, A., Case, J. L., Kim, D., Kim, K.-M., Lau, W., Liu, Y., Shi, J., Starr, D., Tan, Q., Tao, Z., Zaitchik, B. F., Zavodsky, B., Zhang, S. Q., and Zupanski, M.: Integrated modeling of aerosol, cloud, precipitation and land processes at satellite-resolved scales, Environ. Model. Softw., 67, 149-159, https://doi.org/10.1016/j.envsoft.2015.01.007, 2015.

Pommier, M., McLinden, C. A., and Deeter, M.: Relative changes in $\mathrm{CO}$ emissions over megacities based on observations from space, Geophys. Res. Lett., 40, 3766-3771, https://doi.org/10.1002/grl.50704, 2013.

Qu, Z., Henze, D. K., Theys, N., Wang, J., and Wang, W.: Hybrid mass balance/4D-Var joint inversion of $\mathrm{NO}_{x}$ and $\mathrm{SO}_{2}$ emissions in East Asia, J. Geophys. Res., 124, 8203-8224, https://doi.org/10.1029/2018JD030240, 2019.

Randerson, J. T., Van Der Werf, G. R., Giglio, L., Collatz, G. J., and Kasibhatla, P. S.: Global Fire Emissions Database, Version 4.1 (GFEDv4), Oak Ridge National Laboratory Distributed Active Archive Center (ORNL DAAC), Oak Ridge, Tennessee, USA [data set], https://doi.org/10.3334/ORNLDAAC/1293, 2015.

Rieckh, T., Scherllin-Pirscher, B., Ladstädter, F., and Foelsche, U.: Characteristics of tropopause parameters as observed with GPS radio occultation, Atmos. Meas. Tech., 7, 3947-3958, https://doi.org/10.5194/amt-7-3947-2014, 2014.

Rienecker, M. M., Suarez, M. J., Gelaro, R., Todling, R., Bacmeister, J., Liu, E., Bosilovich, M. G., Schubert, S. D., Takacs, L., Kim, G.-K., Bloom, S., Chen, J., Collins, D., Conaty, A., da Silva, A., Gu, W., Joiner, J., Koster, R. D., Lucchesi, R., Molod, A., Owens, T., Pawson, S., Pegion, P., Redder, C. R., Reichle, R., Robertson, F. R., Ruddick. A. G., Sienkiewicz, M., and Woollen, J.: MERRA: NASA's Modern-Era Retrospective Analysis for Research and Applications, J. Climte, 24, 3624-3648, https://doi.org/10.1175/jcli-d-11-00015.1, 2011. 
Seinfeld, J. H. and Pandis, S. N.: Atmospheric chemistry and physics: From air pollution to climate change, 2nd Edn., John Wiley and Sons, New York, 204-275, 2006.

Shi, J. J., Tao, W.-K., Matsui, T., Cifelli, R., Hou, A., Lang, S., Tokay, A., Wang, N.-Y., Peters-Lidard, C., Skofronick-Jackson, G., Rutledge, S., and Petersen, W.: WRF simulations of the 2022 January 2007 snow events over eastern Canada: Comparison with in Situ and satellite observations, J. Appl. Meteorol. Clim., 49, 2246-2266, https://doi.org/10.1175/2010jamc2282.1, 2010.

Tao, Z., Santanello, J. A., Chin, M., Zhou, S., Tan, Q., Kemp, E. M., and Peters-Lidard, C. D.: Effect of land cover on atmospheric processes and air quality over the continental United States - a NASA Unified WRF (NU-WRF) model study, Atmos. Chem. Phys., 13, 6207-6226, https://doi.org/10.5194/acp13-6207-2013, 2013.

Tao, Z., He, H., Sun, C., Tong, D., and Liang, X.-Z.: Impact of fire emissions on U. S. air quality from 1997 to 2016 - A modeling study in the satellite era, Remote Sens.-Basel, 12, 913, https://doi.org/10.3390/rs12060913, 2020.

Tong, D. Q., Lamsal, L., Pan, L., Ding, C., Kim, H., Lee, P., Chai, T., Pickering, K. E., and Stajner, I.: Long-term $\mathrm{NO}_{x}$ trends over large cities in the United States during the great recession: Comparison of satellite retrievals, ground observations, and emission inventories, Atmos. Environ., 107, 70-84, https://doi.org/10.1016/j.atmosenv.2015.01.035, 2015.

US EPA: 2011 National Emissions Inventory, version 2, Technical Support Document, available at: https://www.epa.gov/airemissions-inventories/2011-national-emissions-inventory-neitechnical-support-document (last access: 1 December 2021), 2015.

Valin, L. C., Russell, A. R., and Cohen, R. C.: Variations of $\mathrm{OH}$ radical in an urban plume inferred from $\mathrm{NO}_{2}$ column measurements, Geophys. Res. Lett., 40, 1856-1860, https://doi.org/10.1002/grl.50267, 2013.

van der Werf, G. R., Randerson, J. T., Giglio, L., van Leeuwen, T. T., Chen, Y., Rogers, B. M., Mu, M., van Marle, M. J. E., Morton, D. C., Collatz, G. J., Yokelson, R. J., and Kasibhatla, P. S.: Global fire emissions estimates during 1997-2016, Earth Syst. Sci. Data, 9, 697-720, https://doi.org/10.5194/essd-9-697-2017, 2017.
Veefkind, J. P., Aben, I., McMullan, K., Förster, H., de Vries, J., Otter, G., Claas, J., Eskes, H. J., de Haan, J. F., Kleipool, Q., van Weele, M., Hasekamp, O., Hoogeveen, R., Landgraf, J., Snel, R., Tol, P., Ingmann, P., Voors, R., Kruizinga, B., Vink, R., Visser, H., and Levelt, P. F.: TROPOMI on the ESA Sentinel-5 Precursor: A GMES mission for global observations of the atmospheric composition for climate, air quality and ozone layer applications, Remote Sens. Environ., 120, 70-83, 2012.

Verstraeten, W., Boersma, K., Douros, J., Williams, J., Eskes, H., Liu, F., Beirle, S., and Delcloo, A.: Top-down $\mathrm{NO}_{x}$ emissions of European cities based on the downwind plume of modelled and space-borne tropospheric $\mathrm{NO}_{2}$ columns, Sensors, 18, 2893, https://doi.org/10.3390/s18092893, 2018.

Verhoelst, T., Compernolle, S., Pinardi, G., Lambert, J.-C., Eskes, H. J., Eichmann, K.-U., Fjæraa, A. M., Granville, J., Niemeijer, S., Cede, A., Tiefengraber, M., Hendrick, F., Pazmiño, A., Bais, A., Bazureau, A., Boersma, K. F., Bognar, K., Dehn, A., Donner, S., Elokhov, A., Gebetsberger, M., Goutail, F., Grutter de la Mora, M., Gruzdev, A., Gratsea, M., Hansen, G. H., Irie, H., Jepsen, N., Kanaya, Y., Karagkiozidis, D., Kivi, R., Kreher, K., Levelt, P. F., Liu, C., Müller, M., Navarro Comas, M., Piters, A. J. M., Pommereau, J.-P., Portafaix, T., Prados-Roman, C., Puentedura, O., Querel, R., Remmers, J., Richter, A., Rimmer, J., Rivera Cárdenas, C., Saavedra de Miguel, L., Sinyakov, V. P., Stremme, W., Strong, K., Van Roozendael, M., Veefkind, J. P., Wagner, T., Wittrock, F., Yela González, M., and Zehner, C.: Groundbased validation of the Copernicus Sentinel-5P TROPOMI NO measurements with the NDACC ZSL-DOAS, MAX-DOAS and Pandonia global networks, Atmos. Meas. Tech., 14, 481-510, https://doi.org/10.5194/amt-14-481-2021, 2021.

Zhao, X., Griffin, D., Fioletov, V., McLinden, C., Cede, A., Tiefengraber, M., Müller, M., Bognar, K., Strong, K., Boersma, F., Eskes, H., Davies, J., Ogyu, A., and Lee, S. C.: Assessment of the quality of TROPOMI high-spatial-resolution $\mathrm{NO}_{2}$ data products in the Greater Toronto Area, Atmos. Meas. Tech., 13, 21312159, https://doi.org/10.5194/amt-13-2131-2020, 2020. 